\title{
Las crucifixiones de Bacon y Barceló
}

\author{
Carmen Sabalete Gil *
}

\section{RESUMEN}

En el momento en que la imagen ofrecida no es la esperada, el arte permite que el hombre se interrogue sobre la veracidad del mundo que le rodea. Las crucifixiones de Bacon y Barceló, cuyas desquiciadas formas suplantan al Cristo crucificado, devuelven al ojo su facultad de ver, abren el interrogante acerca del resquebrajamiento del símbolo que representan: permiten que el hombre tome conciencia de su ubicación en la vida. No hay imagen, no hay rostro, que no señale la ausencia de Dios, que no apure la falsedad del sistema. Las crucifixiones de Bacon y Barceló activan esa falta, se hacen parte de ella; la traen al presente. El simbolo se abre al rostro ignorado del otro. La cruz es porosidad, carne. La pintura, materia. La imagen simbólica recupera su potencialidad con ellas.

\begin{abstract}
When the offered image isn't the expected, the art allows the man questioning himself over the world's veracity around him. The Bacon and Barceló's crucifixions, with deranged forms take the place of crucified Crhist, giving back to the eye its faculty of see, open the question about the cracking the symbol they represent: allowing the man to be aware of his position in the life. There isn't image, there isn't face, that doesn't indicate the God's absence, that doesn't show the system's lie. The Bacon and Barceló's crucifixions detonate this lack, because a part of it; bring it to the present. The symbol opens to an unkown face from the other. The cross is porority, meat. The painting, matter. The symbolic image recovers its powerful with those crucifixions.
\end{abstract}

* Licenciada en Historia del Arte, UAM. 


\section{INTRODUCCIÓN: HABLAR DE ARTE SIN SER NADA ARTÍSTICOS}

Todos sabemos que el arte es un gran embaucador, que muchas veces la mentira casa bien con la verdad y que ésta no se necesita muy a menudo. Pero quien ama el arte también conoce, o lo intuye que siempre es mejor, su maravillosa y fecunda capacidad para señalar las sombras, esos intersticios infranqueables e ignorados del hombre. A esos espacios que naufragan en lo desconocido aluden las crucifixiones de Bacon y Barceló: cuadros que nos interpelan incitándonos a ir siempre un poco más allá de nosotros mismos, que pertenecen a ese apartado estético caracterizado por nombrar al mundo y sus cosas con palabras nunca dichas, o lo que es lo mismo, sin ellas. Hay experiencias cuya transmisión no se adscribe a términos conceptuales, puesto que su raigambre, el símbolo al que se deben y presentan (que actualizan, diría Gadamer), precede a cualquier amoldamiento intelectual. Tanto en los tres trípticos de Bacon, Tres estudios de figuras junto a una crucifixión (1944), Tres estudios para una crucifixión (1962) y Crucifixión (1965), como en los tres cuadros de Barceló, Somalia 92 (1992), Caballo crucificado (1998) y Cristo-raiz (1998), se plasma, con toda la connotación sanguínea de esta palabra, con toda su vocación hacia la materia y la carne, el resquebrajamiento de un símbolo. El arte sabe desgranar los argumentos consabidos, desmemoriar sus imágenes en busca del silencio perturbador de lo primigenio, ese que contiene la tormenta y que late en el signo: "Las cosas que me interesan no se pueden decir con palabras. Las cosas interesantes son las que producen ideas y no las que son producto de ideas" '. La pintura pronuncia aquello que la palabra es incapaz de nombrar; "después de todo, si puedes explicarlo (...) para qué te tomas la molestia de pintarlo" "2, dirá Bacon. La pintura puede desajustar suficientemente la mirada como para que, traicicnándolo, fustigándolo, el ojo vuelva a ser ojo y vea qué hay debajo de la apariencia edulcorada del mundo.

Estos seis cuadros, que ante todo son buenos para pensar, provocan un prurito emocional contraproducente para los sentidos. Ponen sobre la mesa la actitud filosófica del arte contemporáneo, ese abocarse fuera de la propia disciplina sin abandonarse un ápice, esa duda acerca de la accesibilidad de todo lo que se nos da a ver y de la propia historia de la pintura. Nada fáciles, y bastante incómodos, nos mueven a cuestionar si no es

\footnotetext{
pág. 41.

2 Pepplatt Michael. Francis Bacon. Anatomía de un enigma. Gedisa editorial. Barcelona, 1999, pág. 127
}

Gıl Iñaki. Miquel Barceló, La Revista de El Mundo. Madrid, 29, marzo, 1993 (págs. 38-41), 
posible que se haya producido el agotamiento del símbolo iconográfico tradicional de la crucifixión, pues traicionan la imagen inmaculada y académica de Cristo crucificado.

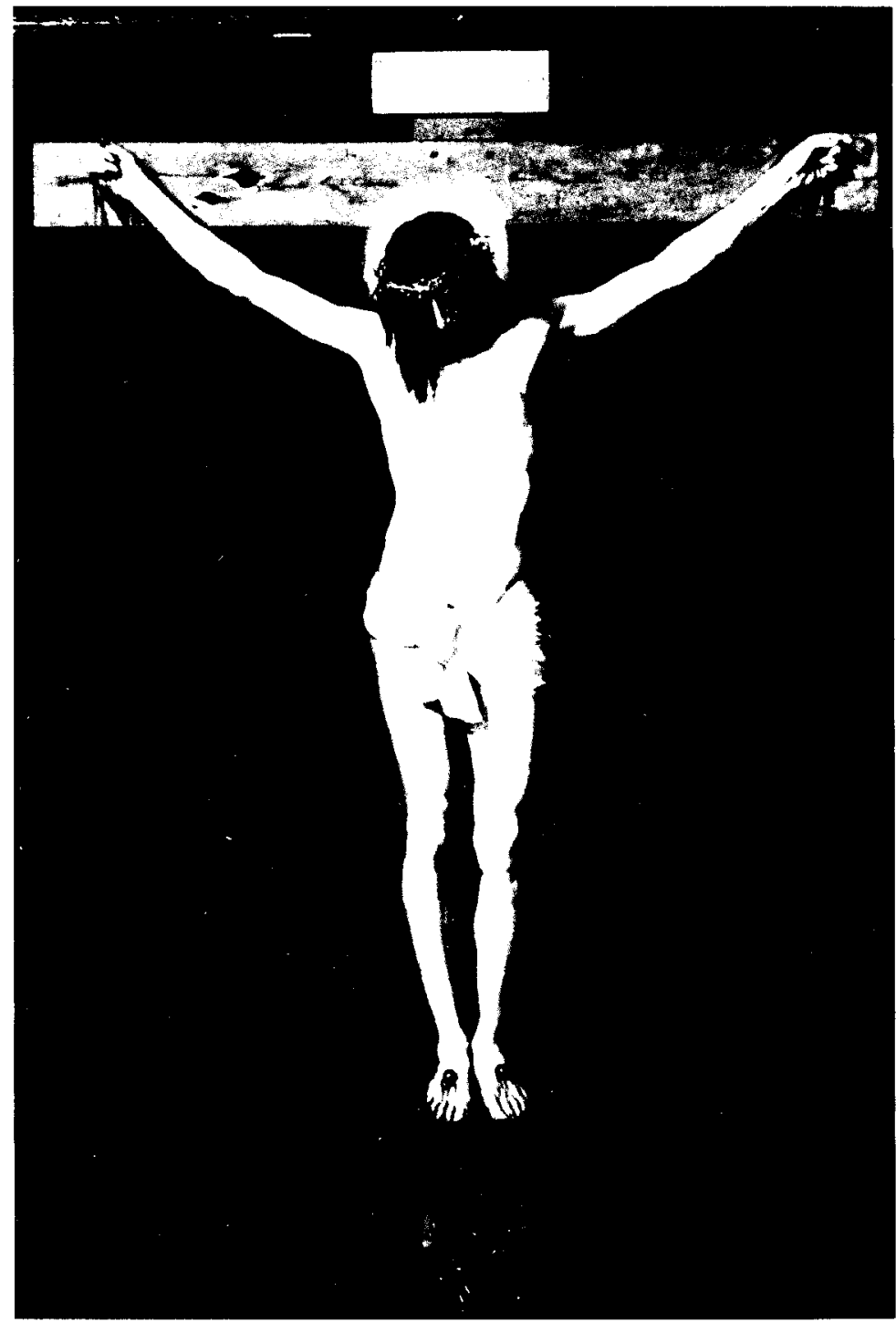

Fig. 2. Cristo crucificado. Autor: Velázquez (hacia 1632). Óleo sobre lienzo, $248 \times 169 \mathrm{~cm}$. Madrid, Museo del Prado. 
En ellos la crucifixión, que en primer lugar y fuera de cualquier adscripción religiosa es una encrucijada de puntos de mira y pensamiento, una suspensión del hombre entre la vida y la muerte como señalaba Cirlot, aparece llena de interrogantes: ¿Ha dejado de ser válida la imagen conocida de Cristo en la cruz para entenderse con el mundo, para "el decir" de la actualidad? ¿Qué se ha roto para que la ordenada figura humana sea suplantada por un animal, para que en lugar de unas plañideras y dolientes mujeres acudan al pie de la cruz unas monstruosas bocas deformadas? ¿Ha cambiado la mirada? ¿Este cambio de mirada acarrea el del símbolo? ¿Se ha agotado el símbolo del hombre doliente en la cruz? Y si es así, ¿cuál es entonces su rostro?

Estos cuadros, que no narran ni leyendas ni alegorias, son "significantes desconocidos" en sí mismos, es decir, armazones, estructuras contenedoras de pensamiento y sentido que no se atienen a un único enunciado o contenido, sino que, pura metamorfosis, prorrumpen en el devenir invitando a un ejercicio de mirada, a "(..) experimentar con la propia experiencia" " , a indagar bordeando la oscuridad, la dificultad: "Las obras de arte no se brindan fácilmente, hacen preguntas, y las obras importantes más preguntas que las demás. Lo que no les impide ser también respuestas. Es decir, que ellas mismas son respuestas a preguntas" " ¿QQué o a quién preguntan las vociferantes figuras de Tres estudios de figuras junto a una crucifixión?

En su cuestionamiento acerca del símbolo que las constituye, las crucifixiones de Bacon y Barceló dejan de ser artísticas mediante una sacudida violenta al sistema nervioso, abandonan la parafernalia brillante del espectáculo, ese único modo de vida del doble artificial, de la copia acomodada y autosatisfecha, cuyo estatuto de unicidad y realidad proclama el simulacro. En ellas un "rasgo intensivo, se pone a actuar por su cuenta, una percepción alucinatoria, una sinestesia, una mutación perversa, un juego de imágenes se libera y la hegemonia del significante queda puesta en entredicho" 5 . No hay campo de acción humana del que no dude la violenta lucha íntima del segundo panel de Tres estudios para una crucifixión. Lucha brutal la de estos cuadros que, inscritos en el contexto posmoderno, con todo lo que éste acarrea acerca de la muerte del arte, y al

Jauss Hans Robert. Pequeña apologia de la experiencia estética. Paidós. Barcelona, 2002. pág. 24.

Waucman Gérard. El objeto del siglo, Amorrutu Editores. Buenos Aires, 2001, pág. 33

Deleuze Gilles, Guattari Félix. Mil mesetas. Capitalismo y esquizofrenia. Pre-Textos. Valencia. 2000, pág. 21. 
tratar el tema de la crucifixión, la muerte o fin de Dios en definitiva, abre la posibilidad de que su muerte rebote en el fin del arte, y éste a su vez en el acabamiento del símbolo representativo de ésta. El arte, al que le gusta hablar honestamente con sus interlocutores, persigue el rostro por excelencia, la imagen ausente de ese dios muerto cuya faz en esta sociedad siempre ha sido la misma, y no lo encuentra. Argullol comenta al respecto: "La 'muerte del arte', aislada de las previsiones de Hegel, se alza como sombra protagonista del arte moderno, en el que se proyecta como desvanecimiento de lo trascendente. Por eso el arte moderno, huérfano de Dios, persigue libre y desesperadamente, a través de la aventura formal una forma de lo divino. Y la experiencia estética es también obligar a que se manifieste aquello con respecto a lo que el hombre moderno se siente abandonado. Ese dios desconocido que ha salido de nuestro escenario y del que, en ciertos momentos, imploramos su retorno" ${ }^{6}$. Estos seis cuadros obligan a que se manifieste esa ausencia, esa herida abierta que no sana. Nos hablan de la carencia que late en la mancha, en el rasgo ínfimamente humano de toda huella. Imágenes desquiciadas, pero sinceras, que buscan ese rostro divino que no brilla, ignorado, que es antes que nada cuerpo y materia, carne sacrificada, nervios rotos. $Y$ para eso cambian diametralmente de registro. Abocan a un arte, que tal como sostiene Jauss, “(...) abra la posibilidad de contemplar el mundo real de otra manera, y en consecuencia permita comprenderse a sí mismo de forma diferente en el otro. Pues el arte autónomo nos muestra lo que ya conocemos de una forma que no conocemos" 7 .

\section{UNA REALIDAD MUY POCO REAL}

El simulacro, en el que lo real ha tocado fondo por saturación y exceso, comercia con una "mercancía gelatinosa" formada por la imagen audiovisual y la información, que profundamente permeable y adaptable, amolda cualquier situación cotidiana. Casi sinónimas, la imagen y la información han adquirido cualidades divinas, pues ubicuas, nuestro mundo no se comprende sin ellas. La imagen audiovisual, fruto de los modernos medios de comunicación (verdaderos reguladores de nuestro horario, de nuestro tiempo de vida y, en tanto que es así, formadores de la conciencia pública), conserva bien poco de su inocencia o ingenuidad, ya que su valor

\footnotetext{
6 Argullol Rafael. 'El arte después de la muerte del arte. Introducción a La actualidad de 10 bello de Hans Georg Gadamer. Paidós. Barcelona, 1997. (págs. 9-23), pág. 19.

Jauss Hans Robert. 'La moral problemática de lo estético': VV. AA. El nuevo espectador.
} 
predominante, en detrimento de su esencia plástica, es el lingüístico. Tal como afirma Pardo, la imagen audiovisual se acompaña de una voz firme y rotunda que la explica-explicita en exceso, que no deja de señalar su cariz de cosa y de someterla a un enunciado; nada de ella escapa de ese mensaje verbal con el que se cifra. Toda imagen se halla enclaustrada en su propia definición. Y en ella, el significado del mundo.

Esta "mercancía gelatinosa", dando un salto cualitativo por encima de sí misma, trascendida y henchida de significado, conforma ese medio ambiente icónico señalado por Gubern, o environment, en el que nos desenvolvemos y que ha replegado por completo al medio ambiente natural. " $\mathrm{La}$ promiscuidad y ubicuidad de las imágenes, la contaminación viral de las cosas por las imágenes, son las características fatales de nuestra cultura" ${ }^{8}$. Nuestra sociedad padece una contaminación icónica atmosférica que enturbia nuestra capacidad de discernimiento y altera las dicotomías (ver$\mathrm{dad} / \mathrm{falsedad}$; bueno/malo, etc.) que forjan el entendimiento y la percepción, hasta tal punto que apreciamos únicamente la alteración en lo que no se ajusta al sistema imperante. Vemos con demasiada facilidad y naturalidad lo cotidiano.

Uno de los rasgos de este medio ambiente icónico, compartido por los objetos industriales del sistema de producción poscapitalista, es la esteticidad. Una esteticidad que crea un efecto trompe l'oeil y que incide aún más en la confusión general, que lleva a la indistinción (al igual que sucede con las dicotomías intelectuales y perceptivas) entre imagen simbólica - laberinto e imagen audiovisual o escénica, pues esta última no está lejos de la investidura de sentido de la primera (las posturas estéticas de Warhol y Duchamp son buenos ejemplos). Aunque a la imagen simbólica se le confiera ese plus de sentido más desde la querella de las imágenes (esa traslatio ad prototypum y transubstanciación que forman parte de su carga simbólica), la imagen audiovisual, mediante su creación de realidad (pese a ser bien diferente de la realidad fenomenológica de la vida natural), posee un valor ontológico propio. Crea mundos, como el infográfico, cuyo valor consiste en su falsedad, pero también en la extensión de nuestros sentidos. Mundos tan reales como éste y que son en última instancia su doble, autónomo e ingobernable, y cuyas imágenes son una duplicación, ur vano mirarse en el espejo, pues su mensaje sólo va en beneficio de los intereses y valores predominantes. La voz que acompaña a la imagen audiovisual, más que pertenecer a su ámbito secreto, a su esencia, forma

8 Baudrillard Jean. El otro por si mismo. Anagrama, Barcelona, 2001, pág. 31. 
parte de la información que al sistema le conviene hacer llegar. ¿Cómo afecta este medio ambiente icónico, que repliega cualquier imagen a una reduplicación de este mundo conocido, a las imágenes tradicionales de la muerte de Cristo? $O$ en otro sentido ¿desconocedoras del simulacro, inscritas en él al emplear los mismos instrumentos de éste (ese acercarse a la realidad sin tergiversarla, ese atenerse fielmente al modelo) han podido transmitir el mensaje que pretendían comunicar? ¿Cómo responden a este environment las crucifixiones de Bacon y Barceló?

Imágenes indescifrables, revulsivas ante la norma, las crucifixiones de Bacon y Barceló mantienen un aliento vital que, exangüe, conserva la tensión cruda y exasperada de la escena que representan. Se saben heridas y "presentifican" (traen al presente) en sí mismas la crucifixión. Actúan desde prismas nunca antes contemplados (desde la desfiguración, la descarnadura; desde la conexión y el intercambio entre corporeidades diferentes). No se da una sustitución o una adaptación a un prototipo referencial, sino una verdadera comprensión de lo representado. Y su tiempo, esa "presentificación", ese poner en acto, nada tiene que ver con el presente de la imagen audiovisual, pues a diferencia de éste, que acorde con cualquier objeto del sistema productivo poscapitalista es efímero, sustituible, y cuya constante presencia sólo remarca su falta de asentamiento y durabilidad (es fácilmente suplantado), su presente no se encasilla en un tiempo dado, en una situación histórica concreta, sino que es el de la fiesta y el juego. Tiempo, como Bataille indica, de la transgresión: espacio del arte, donde el rostro divino es el amasijo de carne desgarrada del panel central de Crucifixión; donde el dolor del cuerpo sacrificado, su sangre, se materializa en raíz (Cristo-raiz). Transgresiones que indagan, inflamadas en su representación, significados, y cuya capacidad temporal se comporta como sujeto, verbo y predicado a la vez: es todo un movimiento sintáctico, toda una acción global que pertenece al ámbito simbólico. Los grandes fondos vacíos de estos cuadros destierran la escena de cualquier contexto histórico, con lo que su mensaje se enclava aun más en un «aquí y ahora" atemporal, válido para cualquier persona. El tiempo se ahonda tanto en ellos que revierte y cae como la figura de Caballo crucificado. Y si esto es así, si esos grandes fondos conjuran toda una acción temporal, todo un movimiento entre intensidades diferentes (ese tiempo que sólo se concibe atendiendo al propio espíritu como dirá san Agustín) se debe a que están intrincados en la crudeza de la existencia. Toda existencia es un crimen, toda existencia mata a su doble, dado que la simple instauración de las cosas niega la posibilidad de otra forma de que se presenten. Sin embargo, aquí ya no es san Pablo el que se cae del caballo, sino éste el que increpa la realidad y suplanta la figura del hombre en la cruz. Rosset 


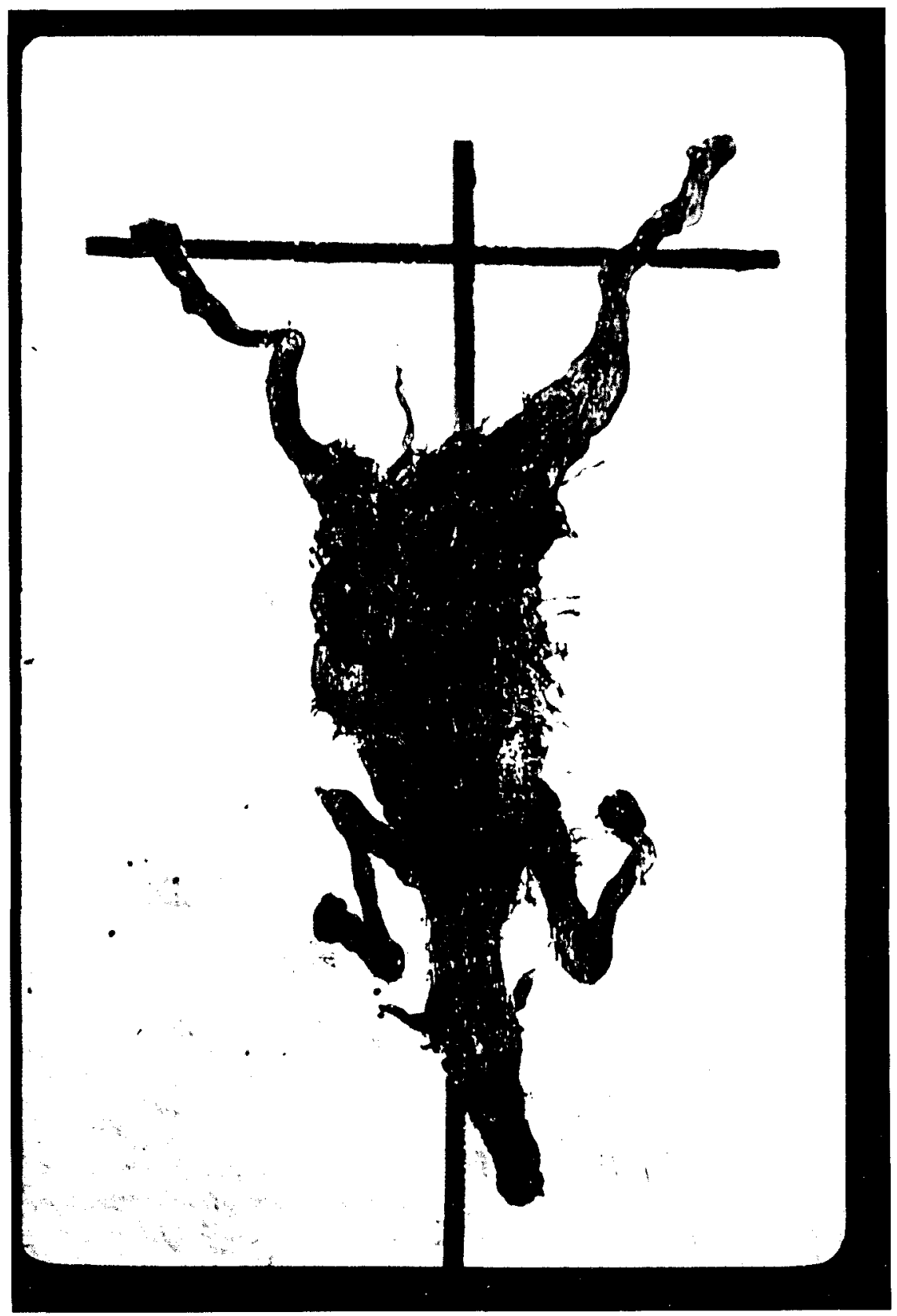

Fig. 8. Caballo crucificado. Autor: Miquel Barceló (1998), técnica mixta en papel montado sobre lienzo. $385 \times 296 \mathrm{~cm}$. Zúrich Galeria B. Bischofberger. 
nos dice: "Por "crueldad" de lo real entiendo en primera instancia, ni que decir tiene, la naturaleza intrínsecamente dolorosa y trágica de la realidad (...). Pero también entiendo por crueldad de lo real el carácter único y, por lo tanto, irremediable e inapelable de esa realidad -carácter que impide, a la vez, mantenerla a distancia y atenuar su rigor tomando en consideración una instancia cualquiera que fuese exterior a ella-Cruor, de donde deriva crudelis (cruel), asi como crudus (crudo, no digerido, indigesto), designa la carne despellejada y sangrienta: o sea la cosa misma desprovista de sus atavios o aderezos habituales, en este caso, la piel, y reducida de ese modo a su única realidad, tan sangrante como indigesta" ${ }^{9}$. Es a este carácter crudo e indigesto de la crucifixión, como acto irremediable que tuvo lugar, que ni se evitó ni se puede borrar, al que se atienen estos cuadros: niegan el simulacro, la mentira de la imagen audiovisual que no supone un crimen sino una reduplicación adulterada del estado de cosas. Si son violentos, si son crueles, lo son en la misma medida en que la realidad, que siempre acaba sucediendo de la forma que menos esperábamos, que siempre nos pilla por sorpresa (nada sabe de esperanzas), es irremediable. $Y$ el color es uno de los recursos de esta violencia. La intensidad febril de los fondos baconianos, en los que la fuerza nerviosa y eléctrica del naranja predomina, contrasta con los desérticos fondos blanquecinos de Barceló.

En los tres trípticos de Bacon el rojo y el naranja recuerdan al tradicional telón de los escenarios teatrales y los grandes paneles de Rothko $y$ adquieren una densidad tremenda y abrupta que estalla en las figuras deshechas. La atmósfera onírica que recrean, de pesadilla brutal, se vincula con la atmósfera primigenia del inicio del mundo y del mito (Arnheim sostiene que el rojo es el tercer nombre de color que toda cultura es capaz de establecer en sus inicios, tras designar la claridad y oscuridad). Son fondos viscosos, del interior del esófago (Bacon amaba las bocas), relacionados con los jugos gástricos y la deglución, con esos procesos fisiológicos que significan también transformación y metamorfosis, trasvase e intercambio: metamorfosis del alimento en nutrientes, de la carne en cuerpo: metamorfosis de la ausencia en presencia, de la imagen en símbolo. Y el negro que tapia los tres vanos del panel central de Tres estudios para una crucifixión, anegando de oscuridad la perspectiva que desde el renacimiento ha supuesto la ventana, que llena de luz se abría a escenas secundarias, que incitaba a la recreación de mundos paralelos al ofrecido en primer término, no sólo insiste en que el espectador se

9 Rosset Clément. El principio de crueldad. Pre-Textos, Valencia, 1994, págs. 21 y 22. 

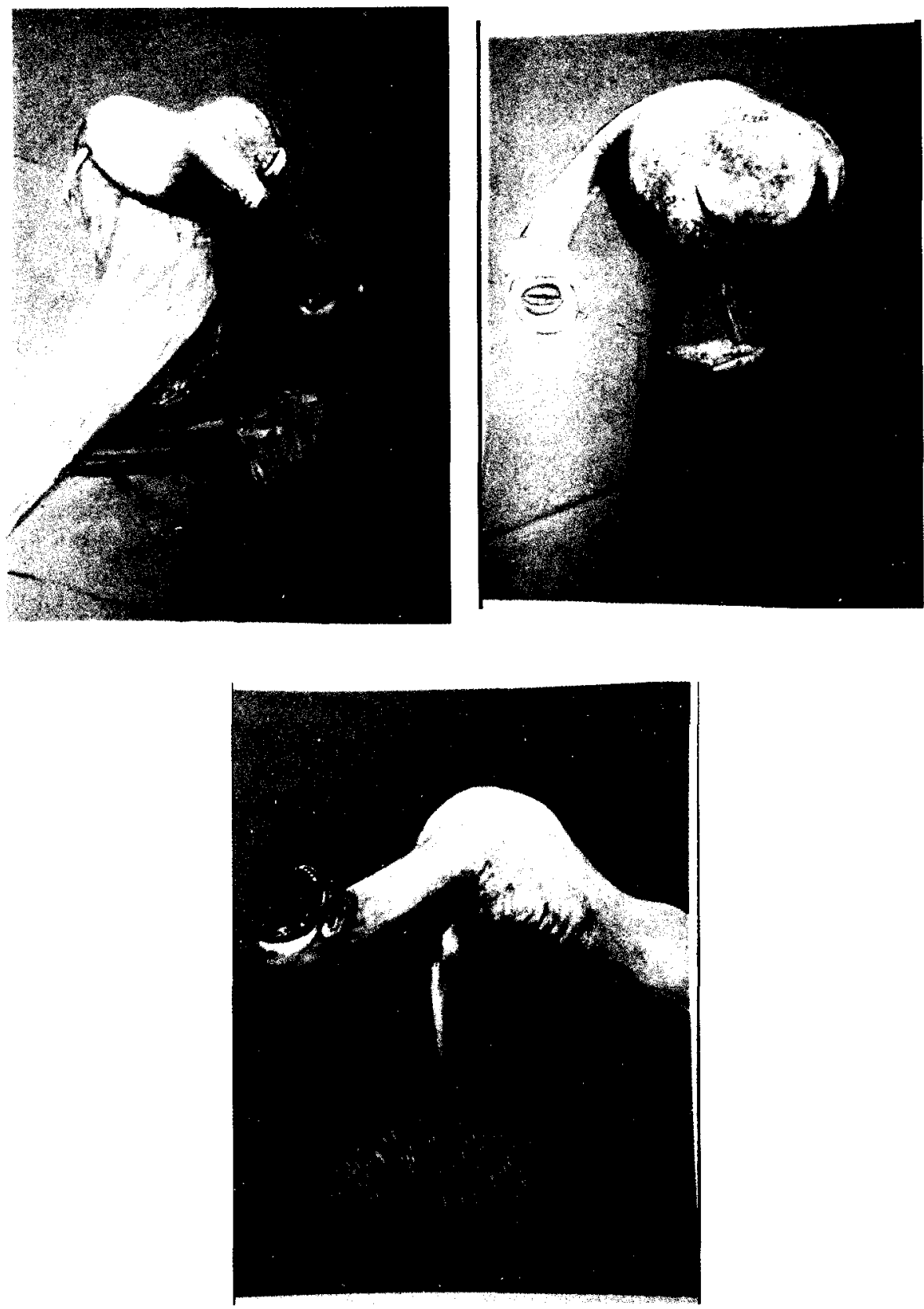

Fig. 4. Tres estudios de figuras junto a una crucifixión. Autor: Francis Bacon (1944). Óleo y pastel sobre cartón. Triptico, cada panel: $94 \times 74 \mathrm{~cm}$. Londres, The Tate Gallery. 

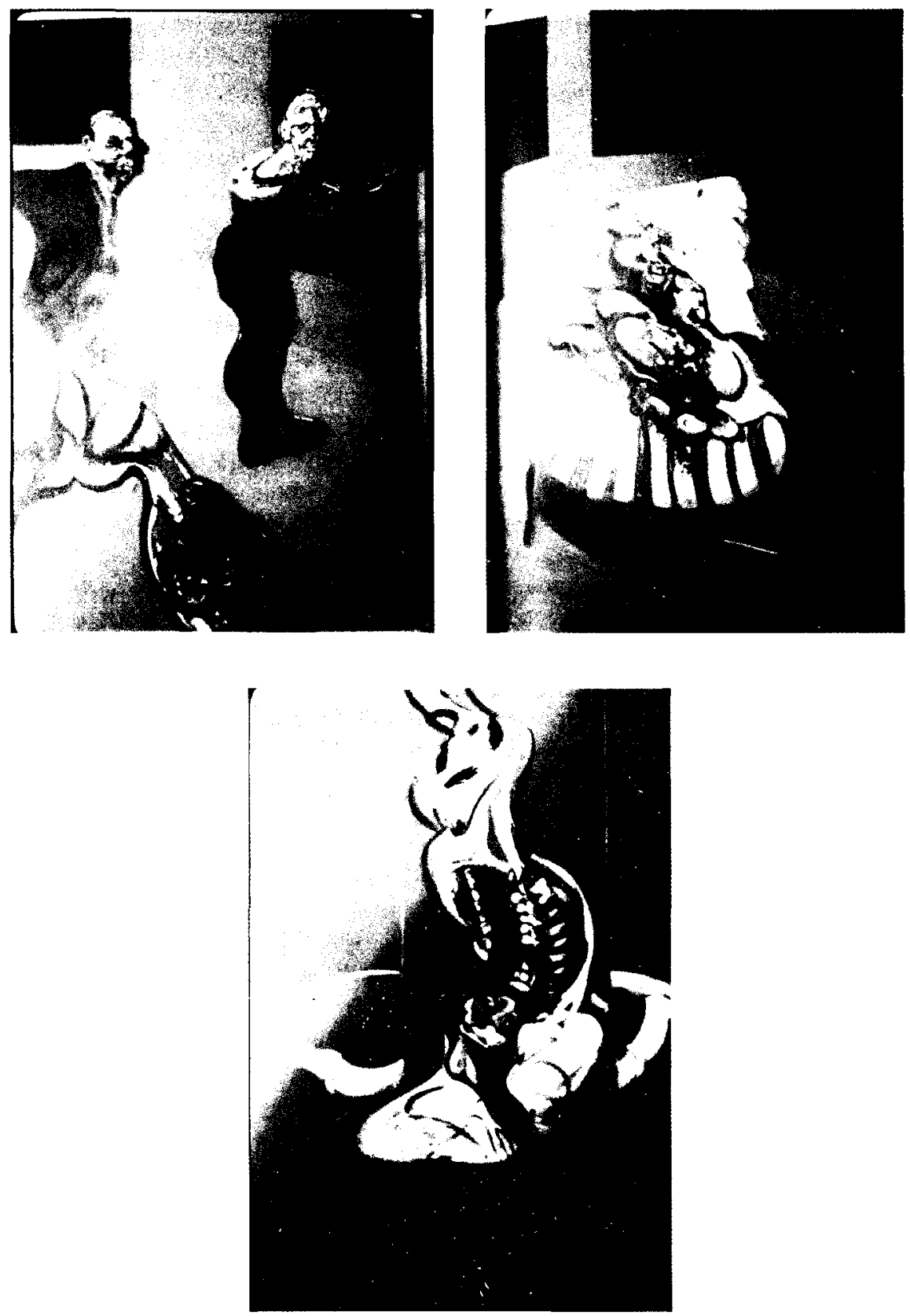

Fig. 5. Tres estudios para una crucifixión. Autor: Francis Bacon (1962). Óleo sobre tela. Triptico, cada panel: $198 \times 145 \mathrm{~cm}$. Nueva York, Guggenheim. 
concentre en la escena ofrecida, sino que es toda una alusión a las tres cruces del monte Calvario. Una premonición de la muerte y el sacrificio que está en eje paralelo con la lucha fratricida que se libra en la cama de la zona inferior.

Si la furia de los fondos baconianos se desata en la desfiguración de los principales personajes, a excepción de Somalia 92, realizado con violentos y grandes brochazos de pintura, el blanco mantiene latente la tensión y dinámica de los barcelonianos, apaciguada como las voces de los periódicos que cubre (Cristo-raíz y Caballo crucificado se han realizado sobre papel de periódico montado a su vez sobre lienzo). Se trata del blanco algodonoso con que se sella la boca de los difuntos en los hospitales, el blanco de la venda que inútilmente separa la vida de la muerte, que sentencia una división inexistente. ¿Hasta qué punto este blanco se corresponde (lo secunda en lo que puede ser su segunda etapa) con los naranjas y rojos de Bacon? ¿No es posible entender que esos colores cálidos que braman y que, más que hirientes, sufren, son la locura que dará paso a ese blanco mortal que neutraliza y aleja? ¿No acalla este blanco los gritos de los colores baconianos que, en último término, se pueden relacionar con las siempre vociferantes noticias de los periódicos? Y el negro de las enjutas figuras barcelonianas, ¿se corresponde acaso con esos vanos oscuros de Bacon?

\section{NECESIDAD DE LA MIRADA ESQUIZOFRÉNICA}

Toda realidad tiene su mirada comprometida. Mirada que da testimonio de que es verdadera, que la dota de peso. Cada época histórica induce a que se mire (y se comprenda) de determinada manera: el ojo no es un perceptor neutro ni inocente. En el simulacro se produce una adulteración del estado normal, valor de uso, de las cosas. La apariencia de éstas, su esteticidad, solapa su utilidad o función. Así, de la misma forma que no se produce una clara distinción entre un objeto cotidiano, sin pretensión estética por bello que sea, y una obra de arte (entre una imagen audiovisual y una imagen simbólica), tampoco existe diferencia alguna entre la forma de ver o de acudir a las cosas. Nuestra sociedad promueve una percepción híbrida, deformada, que eclipsa la distancia. Esa distancia tan necesaria entre la realidad y el individuo para comprender qué es lo real, y que desde Kant se relaciona con la experiencia estética. Estos cuadros, que son ajenos a la imagen académica, solicitan una mirada esquizofrénica que en su vorágine sea capaz de registrar la locura sistematizada del vivir cotidiano. Una mirada que salte la linde, que se anticipe a lo ofrecido. 
Arrojan sobre el mundo una mirada descarnada, que mira directamente a la verdad, que no se amolda a lo preestablecido, sino que profundamente honesta y franca, sólo puede ser virulenta ante el horror que ve: lo terrible si se somete a la expresión clásica, al canon-cuerpo, termina siendo sólo una excepción anormal del mundo ordenado, ese grado de deformación permitido para que las cosas sigan siendo lo que son y tal y como están. Pero si se libera del modelo da paso a un mundo completamente desconocido, un mundo que no niega ni el caos ni la locura, que se despoja de la moral inflexible de la norma y que, al desvestirse de convencionalismos, hace llegar el mensaje verdadero. Las palabras de Saura explicando su concepto de mirada cruel nos sirven para entender esta mirada esquizofrénica: "La mirada cruel supone a un tiempo la desnudez y la permanencia de las huellas de su acción - fulgor de la pincelada, arrepentimiento, superposición e inacabamiento-, tanto como la evidencia de la estructura que la sostiene o la pasión por el fantasma que la nutre. La mirada cruel comprende la gracia angélica de lo inacabado, pues el problema no sería tanto el de saber cómo terminar un cuadro, sino el de saber cómo no terminarlo (...). La mirada cruel, como consecuencia de una forma particular del Mal, no es "historia del arte", sino la historia de la intensidad. Un ansia, una llamarada, la más hermosa y desgarrada; un poder, en suma, en donde su objetivo sublime supone un rechazo de la belleza instituida en función de una erosión y corrupción del lenguaje pictórico para devolverlo a su esencia monstruosa y aberrante " ${ }^{10}$. Mirada cruel, mirada asesina que, espantada de su propio horror, se venda los ojos inútilmente como en Tres estudios de figuras junto a una crucifixión.

La mirada de estos cuadros que citan al hombre desde lo que no es hombre alude a un desvelamiento que se muestra como ocultación, tal como Heidegger entendía la capacidad de hablar del arte desde un doble movimiento de revelación y ocultación o retiro. Nada tiene que ver con la transparencia excesivamente expuesta de la imagen audiovisual, de ese environment. A diferencia de lo que sucede en el simulacro, que con la incitación al deseo y esteticidad exige la fijeza de la mirada, la constante apreciación de sus objetos e imágenes, las crucifixiones de Bacon y Barceló permiten que se aparte la vista, en el sentido de establecer cierta distancia receptiva (de pensamiento y sensibilidad) entre la obra y el espectador. La extrañeza del amasijo de huesos y carne de los cuadros de Bacon y los animales de Barceló, ese Cristo que deviene tubérculo, exilia

:0 Saura Antonio. Fijeza (ensayos). Círculo de Lectores. Barcelona, 1999, págs. 174, 175 y 176. 
a las figuras del cuerpo conocido; exilio que pertenece a un estado de conciencia intenso, desesperado, que exige del espectador una gran «alergia espiritual" que le permita reconocer (ver por primera vez) lo que se le presenta. La mirada esquizofrénica es la mirada del segador de Van Gogh: pura acción, recuperación febril del mundo. Asume, desde ese movimiento ambiguo que aúna la desocultación y la revelación, el devenir, la multiplicidad del no ser y ser, los roces internos entre intensidades, el cambio brusco de velocidad, las voces extrañas de nuestro interior que pertenecen a ese otro que nos habita y no deja de humanizarnos: todo aquello que nuestra sociedad tapiza y allana con sus imágenes consabidas. Y para ello, desde luego, provocan toda una conmoción sensorial. De Maistre, que tanto influyó en Bacon, decía: "En esta vida se debería ser amable y paciente (...), pero en el arte, el comportamiento tendria que ser muy diferente. De hecho, con frecuencia, resulta necesario propinar al espectador un desagradable gancho de izquierda" "1. Un gancho de izquierda que responde al desbarajuste de todos los sentidos rimbaudiano, que no rechaza los distintos niveles interpretativos de una imagen sometiéndolos a uno solo, sino que los entremezcla y los convierte en otros invirtiéndolos y multiplicándolos, para que por fin la imagen resultante hable con el mundo, pertenezca a él: "Yo sólo trato de hacer una pintura que tenga relación con el mundo, no que lo represente ni lo imite, sólo que hable con él»" ${ }^{12}$. Tal vez la forma más sincera de pertenecer a este mundo sea apartarse de él, señalar sus resquicios, su enajenación respecto de lo que verdaderamente es real y cierto. Bacon dirá: "Las cosas no son impactantes si no se las ha colocado de una forma memorable (...). Entonces tendrán significados mucho más amplios. Es algo que resuena dentro de la psiquis, perturba todo el ciclo vital en el interior de una persona. Afecta a la atmósfera en que vive. La mayor parte de lo que se denomina arte, vuestra mirada fluye por encima de él. Puede ser encantador o agradable, pero no os cambia" "13. Y desde luego que la mirada no fluye por encima de estos cuadros. Bernard Goy nos dice respecto de Somalia 92: "Veo Somalia 92 de Miquel Barceló como una imagen invertida en la cual lo que se exhibe ya no es la superficie aceptable, preconceptualizada (o predigerida) por nuestros medios de comunicación, sino la superficie escondida que ha estado en contacto con el crimen, que una de las caras ocultaba en nuestra pantalla y que la otra ha calcado. Andy Warhol calcaba las imá-

\footnotetext{
1 Peppiatt Michael. Op. Cit., pág. 71

12 Soldevilla Rafael. Miquel Barceló. Revista Man. № 125. Madrid, marzo de 1998. (págs. 4044), pág. 42.

${ }_{13}$ PePPIATt Michael. Op. Cit., pág. 359.
} 
genes de las cosas dejando suponer que jamás veíamos las cosas en sí. Barceló, cuya obra es por lo menos igual de subversiva, les da la vuelta» ${ }^{14}$. Por su parte Bacon sostiene: «El arte verdaderamente original estaba destinado a ofender" ${ }^{15}$. Como Daniel Bell afirma, el arte moderno "(...) es conscientemente experimental y busca de un modo deliberado escandalizar al público, inquietarlo, sacudirlo, y hasta transformarlo, como en una conversión religiosa" ${ }^{16}$.

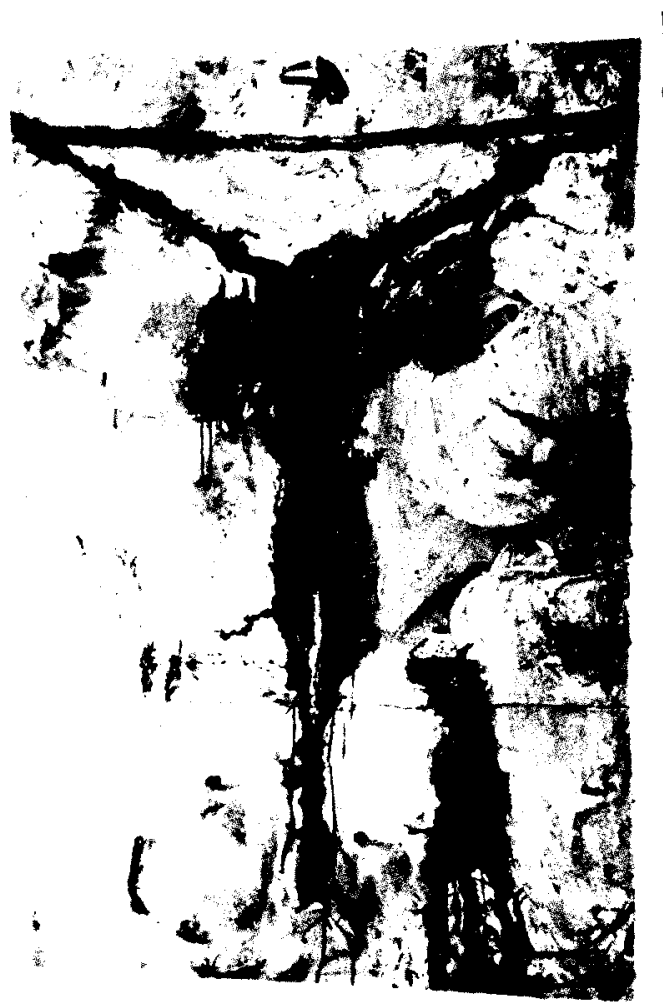

Fig. 7. Somalia 92. Autor: Miquel Barceló (1992), técnica mixta sobre lienzo. $195 \times 130 \mathrm{~cm}$. Colección del artista.

14 Goy Bernard. 'Naturalezas muertas frescas'. Catálogo exposición Miquel Barceló. 19871997. MACBA. Barcelona, 1998. (págs. 60-63), pág. 62.

15 Pepplatt Michael. Op. Cit., pág. 139.

16. AZNAR Sagrario. Agresores y victimas: el sacrificio del artista. Revista Espacio, tiempo y forma. Serie VII. UNED. Madrid, 1997. (págs. 367-401), pág. 370. 
Las crucifixiones de Bacon y Barceló tienen mucho de catarsis religiosa. La contraposición, a cada lado del crucificado, entre las espigas de Somalia 92 y el potrillo que asustado lo mira es fiel al misterio de la dualidad de la cruz: esa esperanza que desde el miedo y el hambre, desde la crudeza de la muerte (potrillo), se levanta hacia la benignidad y belleza de la vida (espigas). Se trata de mostrar ese estrato de lo real dentro de la realidad hecho de carne y vísceras, de convulsión y derrota, y cuyo conocimiento (mensaje) sólo es asimilable por medio de la experiencia misma de la carne. Experiencia que pertenece a la vida y no a la pantalla. Experiencia artística y simbólica por antonomasia. El terror viene después cuando se descubre que la realidad no se modifica, que la verdad no tergiversa sus contenidos, que la víctima y el verdugo son una misma persona: "No podemos ser humanos sin haber sentido en nosotros la posibilidad del sufrimiento, y también la de la abyección. No somos sólo posibles víctimas del verdugo: el verdugo es nuestro semejante. Todavía podemos preguntarnos si existe algo en nuestra naturaleza que haga imposible tanto horror. $Y$ hemos de respondernos que, en realidad, no existe nada" ${ }^{17}$. La ofensa aparece cuando no se quiere reconocer que las cosas no sólo poseen la apariencia dictada, sino que en su interior guardan, igual que la palabra sin pronunciar acoge un silencio intimo que la nombra mejor que el sonido de sus sílabas, un más allá desconocido. Un mundo otro. De ahí su aspecto horrendo: "Yo siempre deseé hacer las cosas tan directas y crudas como podrian llegar a serlo, y quizá, si las cosas van directamente a la gente, ésta piensa que son terroríficas» ${ }^{18}$.

\section{YO ES OTRO}

El otro siempre se ha vivido como una amenaza y más en esta sociedad que, como afirma Lipovetsky, invita al descanso, al descompromiso emocional y a la indiferencia, y en la que el yo es un espacio fluctuante abierto a invasiones de toda índole. El otro es aquel que no cumple las directrices de lo establecido, en quien la sociedad ve la vulnerabilidad de su estado de cosas. El otro, el realmente ajeno, siempre es un monstruo y como tal revela la deformidad del orden: "El monstruo no es más que la monstruosidad del Orden que le segrega, pero debe ser presentado por éste como infractor de la ley, y su exilio vergonzoso como merecido casti-

17 Scarpetta Guy. 'Crucifixiones', recopilado en el catálogo de la exposición Saura desenari 1980-1990. Ayuntamiento de Barcelona. Barcelona, 1991, pág. 244.

18 Sylvester David. Op. Cit., pág. 48. 
go. La intima y secreta zozobra que corroe el Orden, alarmándose desde dentro por la monstruosidad que consiente y fabrica, se expresa hacia fuera como represión o condena del diferente" ${ }^{19}$. Para no correr riesgos, la sociedad procede creando sus propios otros. Se trata de la "otredad" que se muestra como tal sin serlo, pues está permitida y en tanto que aceptada deja de ser realmente ajena y diferente. El otro que no supone una afrenta al modo de vida estipulado no es otro, sino un sujeto que duplica, tan sólo que inversamente, la sociedad que lo crea, lo mismo que la imagen audiovisual reproduce lo convencional. Lejos del superhombre con el que la publicidad engatusa nuestros sueños de ser mejores, lejos también de ese sujeto fractal del que habla Baudrillard (ese hombre que vive escindido y que tan bien representan las figuras baconianas que parecen seccionadas por la mitad; por ejemplo, las sentadas en el pupitre del tercer panel de Crucifixión), el hombre se posee menos cuanto más contempla su interioridad.

Apoyándonos en Pardo creemos que la doblez, ese pliegue oscuro del yo, es nuestra intimidad más profunda: "El habla humana se caracteriza por un doble (sentido/significado, animalidad/racionalidad) irreductible, y es esta arruga la que constituye la morada de la intimidad" ${ }^{20}$. Nuestra esencia es una arruga o doblez que se siente como un ser ajeno y que la herida sangrante de estos cuadros abre. Es nuestra falta de naturaleza, de asimiento, la que nos hace humanos; ese vivir en el límite, entre dos potenclalidades, de Trías. Es la falta de apoyo, el poderse caer a cada instante, lo que singulariza al hombre: su carencia de base y solidez, su inclinación hacia la muerte que paradójicamente lo liga más a la vida. El yo verdaderamente humano se encuentra en la inclinación que supone mantenerse erguido, y esa inclinación leve, llena de carencias y afectos, que se convierte en susurro de vida, en apoyo imprescindible a pesar de su fragilidad, es de una pluralidad desconocida. Pardo nos dice: «(...) cada uno no es uno sino muchos - y donde- la alteridad característica de la intimidad (que siempre nos es ajena) no es únicamente una alteridad humana sino que incluye, de diversos modos, lo animal, lo vegetal, lo mineral y lo divino" 21 . Y continúa: Todos tenemos - porque vivimos en el tiempo-, no un "otro yo" — un doble o un "alter ego"-, sino un "otro que yo" que deshace nuestro yo. Tengo en mi mismo a otro que me es absolutamente extraño porque al menos parte del tiempo de ese otro es para mí

19 G. Cortes José Miguel. Orden y caos. Un estudio cultural sobre lo monstruoso en el arte. Anagrama, Barcelona, 1997, pág. 20.

20 Pardo José Luis. La intimidad. Pre-Textos. Valencia, 1996, pág. 43.

21 Pardo José Luis. Op. Cit., pág. 170. 

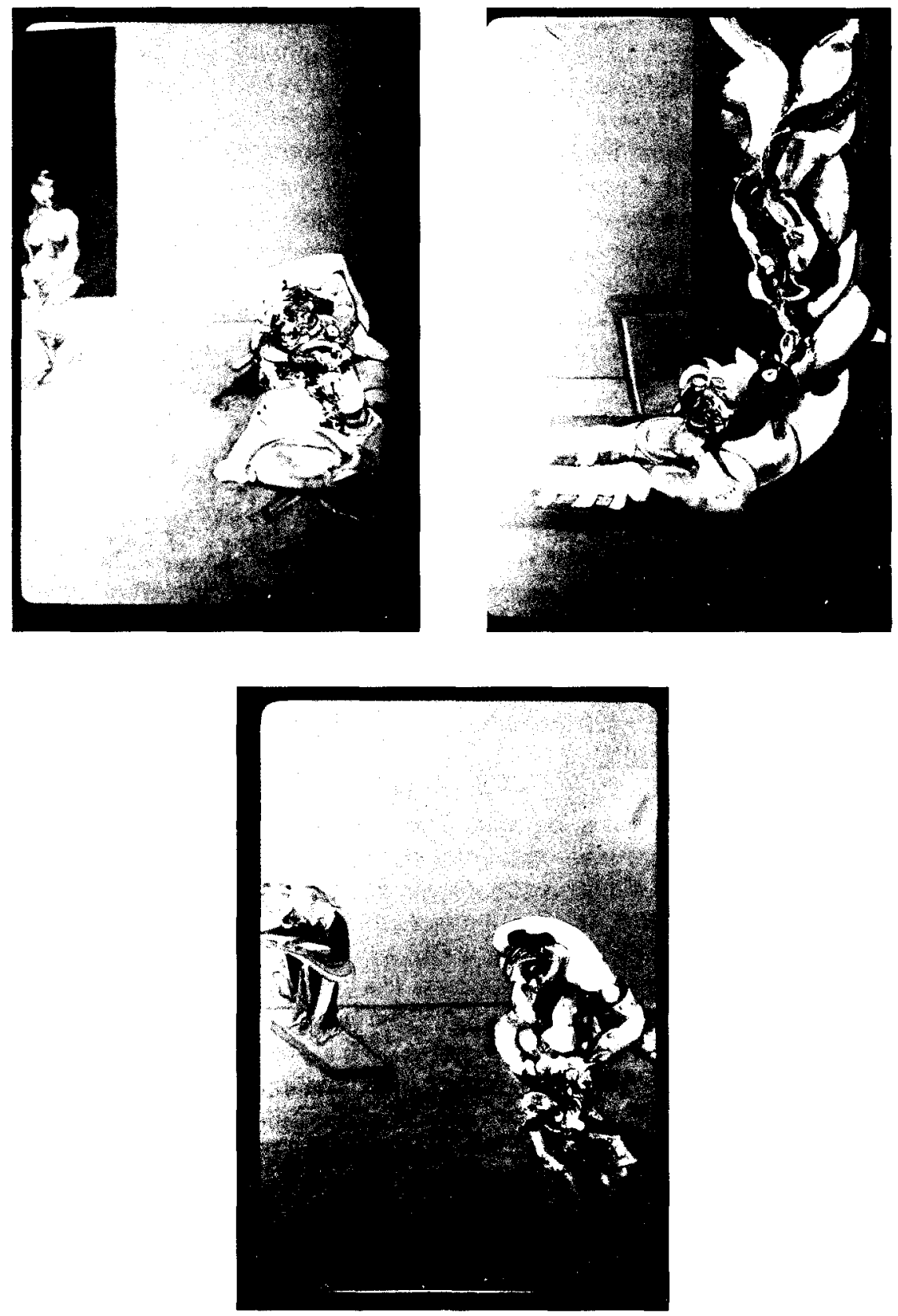

Fig. 6. Crucifixión. Autor: Francis Bacon (1965). Óleo sobre tela. Triptico, cada panel: $198 \times 145 \mathrm{~cm}$. Múnich, Staatsgalerie Moderner Kunst. 
"otro tiempo", un tiempo inaccesible. $Y$, sin embargo, ese tiempo inaccesible, ese tiempo que no es tanto "el tiempo del otro" como "el otro tiempo" o "el tiempo otro" forma parte de mí, está en mí: la unicidad del yo está parcialmente velada, parcialmente olvidada, nadie puede recordar el pasado de otro ni imaginar el porvenir de otro; por ser yo, no puedo "recordar" ni "imaginar" ese pasado y ese futuro que, no obstante, llevo en mi mismo como el monstruo que crece en mi interior" 22.

Este otro de nuestro interior valida una autoconciencia que se erige como la conciencia de un otro ajeno y que en estos cuadros se manifiesta como un desnudamiento de la imagen, un quedarse en cueros de la representación. El yo se desviste de sí mismo para mostrar su "otredad" y se desnuda quitándose su propia piel, su imagen humana, enseñando su multiplicidad. La desnudez de estos cuadros no tiene que ver con la de las anteriores representaciones, pues ése es el desnudo bello de quien se sabe observado, un desnudo que es un continuar vestido, mientras que aquí se está literalmente en cueros; se registra el devenir. Un desnudo de la imagen conocida, que es un arropamiento de carne y heridas muy parecido al descrito en las visiones de la Pasión de Cristo de la religiosa Ana Catalina Emmerich de Westfalia: "Su mucha sangre y la piel destrozada cubrian su desnudez" ${ }^{23}$. Lo mismo que sucede con esos cuerpos baconianos deformes que penden del gancho o luchan en la cama, cuyo amasijo y retorcimiento modela su forma. Se trata de un devenir que, como indican Deleuze y Guattari, no se basa en semejanzas, en una última y primitiva identificación entre el hombre y el animal, sino en la correspondencia entre las relaciones que el animal establece con el mundo y las que el hombre realiza a su vez. Un hombre nunca se dirá "soy un toro" pero sí "soy a la mujer lo que el toro a la vaca". Estos cuadros se hacen eco de esos cambios de dimensión e intensidad, de esa desterritorialización que pone en funcionamiento el devenir: un hombre que va a ser crucificado equivale al animal que va a ser sacrificado; un hombre clavado en una cruz se corresponde con la canal colgada en el matadero; la canal colgada del gancho, guardada en la cámara frigorífica y lista para su consumo, se identifica con el tubérculo que se extrae de la tierra y satisface el apetito humano. El yo es únicamente un umbral que no deja de transformarse. Peppiatt escribe sobre Bacon: "Bacon era muy consciente del animal que el hombre lleva dentro, quizá porque se crió rodeado de animales (...). Este agudo sentido

22 Pardo José Luis. Op. Cit., págs. 169 y 170.

23 Padre Pablo C. P. P. S. La amarga pasión de nuestro señor Jesucristo según las meditaciones de la religiosa Ana Catalina Emmerich de Westfalia apuntadas por Clemente Brentano. Ediciones Sol de Fátima. Madrid, 1985, pág. 114 
de la bestia que hay en el hombre fue lo que empujó a Bacon hacia el motivo de la Crucifixión como un ejemplo sublime de la brutalidad humana y como un tema que le permitió combinar imágenes de los mataderos con varios de los grandes iconos del arte occidental" ${ }^{24}$. Y de nuevo aparece otra coincidencia con las contemplaciones de la religiosa: "Era un espectáculo doloroso el ver a Jesús pálido, desfigurado, cubierto de heridas, el cabello en desorden, su vestido húmedo y manchado, arrastrado con cuerdas y empujado con palos como un pobre animal que conducen al matadero (...)»25. Combinación fantástica de imágenes que vuelve a resonar en las palabras de Deleuze y Guattari: "Cada multiplicidad es simbiótica, reúne en su devenir animales, vegetales, microorganismos, particulas locas, toda una galaxia» 26 . Todo un proceso que termina siendo autobiográfico, cuando Bacon afirma: "Si entro en una carnicería siempre pienso sorprendiéndome que yo no esté alli en lugar del animal’ 27, y cuando Barceló, también extasiado por los mercados de carne de Malí, comenta por su parte: "Si, el bicho ahorcado con el pulpo entre las piernas es literalmente un autorretrato. Mi pintura se mueve entre la alusión al esperma y la muerte. Entre el blanco del zinc, que es el esperma, y el blanco del plomo, que es la muerte. Quizá todo guarde relación con que vivo en un sitio animista donde se realizan sacrificios de animales que luego se comen" ${ }^{28}$. De esta forma, es en el matadero, en ese miedo incontrolable que asalta a la víctima, en ese desgarro de la carne en la cruz, donde se descubre la unicidad del sufrimiento: "El hombre que sufre es una bestia, la bestia que sufre es un animal. Ésta es la realidad" ${ }^{29}$. El devenir no conoce fórmulas ni preceptos.

\section{LA PINTURA COMO JUGO GÁSTRICO. EL MUNDO RECIÉN NOMBRADO}

Para renombrar el mundo, las crucifixiones de Bacon y Barceló, en permanente metamorfosis, entrañan la paradoja de aunar lo crudo (esas figuras viscosas de Bacon) y lo putrefacto (las figuras desecadas de Barceló);

\footnotetext{
24 Pepplatt Michael. Op. Cit., pág. 86.

25 Padre Pablo C.P. P. S. Op. Cit., págs. 64 y 65.

26 Deleuze Gilles, Guattari Félix. Rizoma. Introducción. Pre-Textos. Valencia, 2000, pág. 19.

${ }^{27}$ Sylvester David. Interviews with Francis Bacon. Thames and Hudson. Londres, 1975, pág 46.

28 Rebolras Ramón F. Estoy convirtiéndome en un monstruo. Revista Cambio 16. № 1213 Madrid, 20 de febrero de 1995. (págs. 60-63), pág. 60.

29 Deleuze Gilles. Francis Bacon. Logique de la sensation. Volumen 1. Editions de la Difference. La Colle-sur-Loup, 1984, pág. 21.
} 
estados extremos que, lejos de la cocida y tibia imagen audiovisual, no pueden simularse y que remiten a ese primer paso en toda configuración cultural que va de lo crudo a lo cocido según Lévi-Strauss. Mediante él una comunidad adquiriría, partiendo de lo salvaje (crudo), sus pautas conductivas civilizadas (cocido), que la diferenciarian de cualquier otra, es decir, su sistema de protección. Si en estos cuadros están tan presentes esos estados que el sentido del gusto humano rechaza, que la sociedad prohíbe, se debe a que no se protegen de la que representan, de la materia que son. Nos referimos a esa mater primigenia desordenada de la que todo parte y en la que todo acaba: en una época en la que el yo se tambalea, el cuerpo es el único ámbito capaz de precisar nuestra identidad, ya que es el territorio donde mejor se registran las diferentes conexiones entre elementos y estados, donde la veracidad del proceso experimentado queda patente, deja su huella. Y el cuerpo de las crucifixiones de Bacon y Barceló se atiene por completo a la materia y sus necesidades. Una materia a la que sólo puede responder la necesidad de la pintura. Esa rica pictura picturans de la que ya habló Cirlot en 1957, capaz de ejercer una profunda reflexión desde su propia cualidad plástica y que para hablar no precisa de instrumentos ajenos a los suyos. No se trata pues de una pintura especular (copia o eco del mundo), sino de una pintura intrincada en su propia "fisicidad", seducida por su corporeidad: "Donde la pintura no hablaría más que a sí misma ni más que de sí misma, pintura plena de sí, preocupada nada más que por ella, teniendo por único tema de conversación y por todo horizonte su propia historia, sus obras, sus pompas y el resto" ${ }^{30}$. Un arte autófago que, en una espléndida comprensión de su naturaleza, puede denunciar que también es mera apariencia: "Modernidad de un arte que se tomaría a si mismo por objeto y que se alimentaria con su propia sustancia - ¿autófago?-Arte evolucionado por involucionado, de mirada puramente interior y que se vuelve, se repliega sin cesar sobre si, que escruta su rostro, sondea su corazón y sus riñones, hurga en sus propias entrañas, afanoso de descifrar en ellos todo su pasado y todo su futuro, su ser entero" ${ }^{31}$. Las crucifixiones de Bacon y Barceló se autoacusan, autoseñalan, como deudoras de la historia de la pintura, y al hacerlo reprochan a la yez a las anteriores el ser meros ejercicios de la disciplina. Las bocas terribles de Tres estudios de figuras junto a una crucifixión no cesan de acusarse entre sí.

En este abocarse a la propia disciplina ha de señalarse que si bien Bacon no dejó de acudir a cuadros de maestros anteriores indagando y

\footnotetext{
WaJCMAN Gérard. Op. Cit., pág. 51

WaJCMAN Gérard. Op. Cit., pág. 51.
} 
buceando en torno a ellos, por su parte Barceló comenta sobre la historia de la pintura: "Hay que remirar la pintura para sacar una nueva serie de lecturas. La tradición no es nunca lineal y no hay un proceso evolutivo hacia algo mejor" ${ }^{32}$. La historia de la pintura se renueva en la apreciación del lienzo como un campo de batalla, como un cuerpo sobre el que actuar (la deuda del expresionismo abstracto estadounidense es obvia). Campo en el que pintura y materia se confunden, en el que el óleo se densa de corporeidad. Vozmediano escribe sobre Bacon: "Bacon no ha hecho otra cosa, como pintor, que mostrar el interior del cuerpo: cuerpo y huesos (...). La pintura de Bacon carece de argumento, renuncia a la narrativa para centrarse en el mismo acto de la carne» ${ }^{33}$. De ahi que la carne retorcida, en una apertura que deja escapar al otro monstruoso de nuestro interior, se haga eco de su sufrimiento: "La carne es el objetivo más alto de la piedad de Bacon (...). La carne es la zona común del hombre y la bestia, la sombra de la indiscernabilidad (...) " ${ }^{34}$. La pintura, por ser materia, es carne. Barceló dirá al respecto: "La relación carne/pintura es el centro de todo" ${ }^{35}$, para continuar: “(...) en mi casa daba un corte brutal y trabajaba para mi pues casi sin pintura, es decir, con materia orgánica, incluso a veces en estado de descomposición y cosas asi. Creo que esta especie de esquizofrenia ahora la vuelvo a utilizar. Utilizo todo, la parte académica y la parte digamos libre» ${ }^{36}$. Cristo puede ser sustituido por un caballo, puede en el momento de su muerte transformarse en raíz, como el grano de trigo que ha de morir para florecer.

Y como no puede ser de otra forma la voz de esta pintura picturans abocada a la materia originaria, que es puro acto, pura acción desmembrada, nace de la poesía, de esa imagen princeps, que se anticipa al propio lenguaje y a su ordenamiento lógico, que emerge del instante y sanciona lo imprevisible de la palabra, pues existe gracias a la efervescencia del ser. La poesía es una fenomenología del decir, del alma; pura transitividad en la que el yo individual, siempre intransitivo, dado que sin abandonarse no puede conocer realmente la verdad de otro (siempre es aproximado el conocimiento que tenemos de los demás, pues nuestro yo mismo impide que sintarnos lo que otro experimenta), puede desplegarse y

32 Power Kevin. 'Conversaciones con Miquel Barceló (...)'. Ed. Diputación de Alicante, 1985, recopilado en el catálogo de la exposición Miquel Barceló 1987-1997. Op. Cit., pág. 16.

33 Vozmediano Elena. La cruz como estructura pictórica. Francis Bacon y Antonio Saura. Revista Kalías. № 15-16. IVAM. Valencia, 1996 (págs. 20-30), pág. 24.

34 Deleuze Gilles. Op. Cit., pág. 21

35 Montanya X. 'Entrevista con Miquel Barceló'. El Temps, Barcelona, 6 de junio de 1994. Recopilado en el catálogo de la exposición Miquel Barceló 1987-1997. Op. Cit., pág. 24

36 Rubıo Pilar. Entrevista. Miquel Barceló, artista pintor. Revista Lápiz. № 21. Madrid, diciembre, 1984. (págs. 25-30), pág. 26. 
conjugar realidades, vivir experiencias que por medio de un énfasis imaginativo dejan de ser ajenas, formular la inmediatez de lo extraño: "Vivir, vivir verdaderamente una imagen poética, es conocer en una de sus pequeñas fibras un devenir del ser que es una conciencia de la turbación del ser" ${ }^{37}$. Turbación humana de un ser entreabierto que se desdice y abre. Un ser que se abre a ese estar en medio, entre el no ser y el ser, que se reconoce en el pliegue íntimo entre la duda y la certeza. Así, si la imagen poética corrobora lo imprevisible del lenguaje, y de esta forma es capaz de asumir la libertad de establecer cierta distancia respecto del discurso cotidiano, de discrepar de él, las crucifixiones de Bacon y Barceló, por su parte, exponen la imprescindibilidad de la pintura. La imagen se anticipa al ojo anestesiado. Imagen cuyo proceso creativo se caracteriza por la ausencia de sistema, por la libertad ineludible que sale al paso del enfrentamiento con lo extremo. Barceló comenta sobre su forma de trabajar: "No tengo sistema fijo para nada y para pintar mucho menos. Algunas veces tengo una idea en la cabeza durante mucho tiempo, pero ocurre que a veces estoy haciendo otra cosa, o bueno, porque en ese momento no me apetece, y lo voy guardando y llega un momento en que se me va haciendo bastante claro. Un momento en que la idea se forma muy directamente y muy fuerte, entonces me meto con él y lo acabo. Otras veces lo arrastro durante meses y meses. No hay desde luego una teoria fija. Todo en mi vida es bastante móvil's ${ }^{38}$. El cuadro se resuelve a sí mismo mediante una constante sucesión de imágenes, de ahí en parte que resulten poco hechos, que sean capaces de mostrar esa "crudeza" del asesinato vital. Cuadros indigestos que no esperan a ser solucionados o terminados, sino que se escapan de las manos, veloces como las corrientes intensas de Virilio. Bacon, quien también se basaba, cómo no, en una rutilante sucesión de imágenes para componer sus lienzos ("yo hago una después de otra. Una me sugiere otra" ${ }^{39}$ ) subraya la importancia del azar (toda una deuda surrealista en su caso) o el accidente, sin menospreciar la carga selectiva, de elaboración mental, que acarrea el proceso: "Quizá alguien pueda decir que esto no es un accidente, porque éste llega a ser un proceso selectivo a cuya parte de accidente une la perseverancia (...). Es un asunto muy dificil y oscuro saber cómo surge la pintura, a veces directamente dentro del sistema nervioso y otras obtienes la historia en una larga diatriba a través del cerebro" 40.

37 Bachelard Gaston. La poética del espacio. Fondo de Cultura Económica. Madrid, 2000, pág. 259 .

38 Rubio Pilar. Op. Cit., pág. 29.

39 Sylvester David. Op. Cit., pág. 21

40 Sylvester David. Op. Cit., págs. 17 y 18. 
Sentimiento afín al de Barceló cuando afirma: "Y es mi mismo gesto de remover y nombrar, porque es un poco entre el accidente y la voluntad" ${ }^{41}$. Se trata pues de cuadros desahuciados, no sólo por ser híbridos de carne y pintura, sino porque, como actos genuinos de ese hombre que en su creación intenta equipararse a la divinidad y abandona la imitatio, no pueden sino nacer imperfectos, maltrechos, como es quien los realiza. Cuadros transgresores que son acto de poiesis (poesía), nombre según Platón y Aristóteles del hacer humano en el mundo, pues la condición del hombre en la vida se presenta poiética, es decir, productiva; acción que al pasar del no ser al ser promueve la instauración de las cosas en la forma sin alejarlas de su origen. ¿Acaso no se da en ellos una instauración del hombre en el sufrimiento y la violencia reales de la crucifixión? ¿No es esta entrada repentina en la realidad inscrita en el lienzo la que rompe la ligazón con las anteriores representaciones y la imagen audiovisual, que sólo se autoimitan y reduplican?

Así las cosas, no es extraña la intervención directa y corporal del pintor sobre el cuadro (incluso la modulación de éste por la materia). Hay que meterse de lleno, dejarse arrastrar por la pintura. Hay que experimentar con uno mismo y el lienzo hasta confundir las personalidades, hasta borrar la línea que separa a uno de otro; la mano termina siendo pincel, y éste toma el cuerpo de las termitas que orienta Barceló para aprovechar los orificios con los que horadan la tela. La mano del artista, nunca más lejos del yo autoafirmativo del siglo XIX, deviene animal: el sentido del tacto, ese que la imagen audiovisual no permite, (nuestra sociedad prohibe cualquier acercamiento verdadero al otro, cualquier aproximación que implique un riesgo de mancha), adquiere una importancia enorme, porque el ojo puede tocar al hombre cuando la imagen no es la que se espera, lo mismo que nos zarandea la vida, que nos toca e impulsa, cuando nos da lo imprevisto. Barceló comenta: "Para mí lo de pintar ha sido siempre algo físico, una cosa espesa, sucia. Y es esencial lo de la materia primigenia, el contacto con esa materia» ${ }^{42}$. Contacto directo que Gabriel Rodríguez también destaca de Bacon: "Todo un movimiento pasional recorre su pintura, le obliga a meter la mano en el cuadro, al tacto real como sentido de la verificación, a disfrutar de la materia, de la carne pictórica, en esa búsqueda del otro que es también y fundamentalmente una búsqueda de si mismo, por la que la obra se convierte en espejo, en reflejo, en un autorretrato

41 Ribas José. Miquel Barceló. Revista Ajoblanco. № 49. Barcelona, febrero, 1999. (págs. 25-30), pág. 50.

${ }_{42}$ MURILlo E. Una mirada al centro de la tierra. Revista El europeo. № 17. Madrid, noviembre, 1989. (págs. 89-98), pág. 91. 
construido» ${ }^{43}$. Meter la mano, sentido de la verificación... ¿No son estos cuadros una provocación, no meten el dedo en la llaga, en la verdad de la escena misma que representan? ¿Qué mejor definición del hombre que esa necesidad suya de introducir el dedo en la herida, del contacto directo, para probar la verdad? ¿Qué más humano que la duda tomasiana? Porque ahora se trata de considerar la pintura como una llaga, y de introducir nuestra duda en ella. De interrogarse acerca de si el rostro de Dios no puede devenir animal, "ajenidad". Un corrimiento de sentido que provoque una gran alergia espiritual que nos soliviante, que nos haga sentirnos incómodos. Tanto como lo son estos cuadros, tanto como nos procura evitar este mundo: la incomodidad no va bien para la salud del mando a distancia. La esencia de esta pintura adquiere más carácter de huella o impresión (esa señal o marca que una cosa deja en otra al presionarse contra ella) que de deslizamiento de un pincel sobre el lienzo. Son cuadros que se han dejado infligir, golpear, por una acción (el sacrificio), cuya huella ha quedado impresa en el lienzo, tal como quedaron las rodillas de Cristo al caer al suelo camino del Calvario o como se imprimieron sus manos en la cueva del monte de los Olivos según las visiones de Ana Catalina Emmerich. Hay toda una impresión corporal y anímica en estos lienzos; todo un eco del ciclo vital: esa crudeza que parte de los cuadros baconianos, que toma al hombre como piezas de carniceria, que despedaza la carne, casi viva y latente, y esa podredumbre de los restos del banquete olvidados en la mesa, del final de la cena, de las figuras resecas de Barceló. Toda una sugerencia sobre el principio y fin de la comida, sobre la apropiación cultural del hombre. Toda una intromisión en el símbolo binario de la cruz, entre la vida y la muerte, entre la potencia conjuntiva (creativa) y la disyuntiva (destructiva). Cuestión abrumadora que pertenece al ámbito simbólico y que recupera las voces ancestrales de la pintura, ese resquicio protector de la caverna, de cuyas deformaciones se sirvió para incitar la vida: "Las irregularidades de la roca fueron aprovechadas para imitar los volúmenes de los animales, como si la materia se hubiera amoldado a la presión del animal contra el muro y hubiera impreso su forma en negativo (...). El gesto de apoyar firmemente uria mano bien abierta sobre una superficie (...) preludia quizá el gesto de Tomás ante Cristo cuando quiso asegurarse de que no se hallaba ante ninguna fantasmagoria» "44.

43 Rodriguez Gabriel. 'Francis Bacon. La pasión por lo real', recopilado en el catálogo de la exposición Francis Bacon. Casal Solleric. Ayuntamiento de Palma de Mallorca. Palma de Mallorca, 1998. (págs. 11-14), pág. 13.

44 AzARA Pedro. El ojo y la sombra. Una mirada al retrato en Occidente. Editorial Gustavo Gili. Barcelona, 2002, pág. 50 . 
Tocar y asegurarnos, tocar el cuadro y que nos toque a su vez. La duda revierte impresa en nosotros. Imagen simbólica que deja ver el origen prohibido.

\section{RESQUEBRAJAMIENTO DEL SÍMBOLO. EL ROSTRO IGNORADO DE DIOS}

El símbolo es enigma, evocación de lo ausente, como el mito, principio. Territorio de la imagen simbólica, ¿qué falta o carencia puede evocar la transparente y ubicua imagen audiovisual? La imagen simbólica teje su laberinto en torno a lo desconocido, a lo prohibido, ámbito de lo sagrado, pues como Bataille indica lo sagrado marca la franja de lo que nunca se conocerá. Estos cuadros, que abandonan el realismo, la imagen estipula$\mathrm{da}$, que son "(...) la expresión de un significado que es imposible representar por otro medio que no sea el símbolo" ${ }^{45}$, no pueden comprometerse con la forma académica. El símbolo no hace concesiones. Todo lo contrario. Su carácter dinámico, polisémico, no puede atenerse a una única imagen. No puede ceñirse, no admite síntesis o concisión, puesto que su realidad interna se halla en una tensión entre significante y significado tal que no puede doblegarse. Juega con el desconocimiento y lo indescifrable. Gadamer nos recuerda: "(...) 10 simbólico, y en particular 10 simbólico del arte, descansa sobre un insoluble juego de contrarios, de mostración y ocultación" " ${ }^{46}$. Como la cruz. Esta conjunción de contrarios, que se identifica con ese movimiento de revelación y ocultación que para Heidegger designa la forma de hablar del arte, con ese frágil pero maravilloso paso del no ser al ser de la poiesis, con la desazón de lo crudo y ia impiedad de lo putrefacto (formas todas que se entrevén en estos cuadros) trama una línea discontinua entre diferentes disciplinas académicas que arroja luz sobre el significado de la muerte de Cristo, sobre el símbolo que se regenera en estos cuadros impíos. Gracias a este engranaje, a ese afloramiento que posibilita el arte, se puede desmantelar el funcionamiento mítico al que las anteriores representaciones no han dejado de obedecer. El mito, que posee una función tanto fundacional y legitimadora como deslegitimadora, reencuentra su función dinámica y metamórfica en la extrañeza de un tubérculo dios, de un amasijo amante de su propia carne.

45 MARdones José María. El retorno del mito. Editorial Sintesis. Madrid, 2000, pág. 28 
Si como Baudrillard señala "el crimen está en el arranque de todas las culturas como el acting-out por excelencia" ${ }^{47}$, el sacrificio es uno de los pilares básicos de la constitución cultural. Y en nuestra sociedad, el sacrificio por excelencia, todo un referente mítico, es la crucifixión. Así, Girard expone la violencia como el fenómeno por antonomasia de toda institucionalización: el ser humano, que es un ser de deseo, también es un ser mimético (el niño aprende imitando). De ahí que este deseo sea también aprendido y que pueda entenderse como un deseo social que tiene su parte positiva (se pueden copiar o aprender las acciones nobles), como negativa (algo que anhelan muchos puede llevar al enfrentamiento intestino de la comunidad, con lo que sus miembros se convertirían en antagonistas). Para Girard cualquier disensión interna deriva de esta primera y debe reprimirse para que no degenere en una crisis mimética que destruya la misma comunidad. $Y$ una forma inconsciente de hacerlo es proyectar ese antagonismo sobre un chivo expiatorio (imitar mediante el rito el primer sacrificio, el asesinato fundador de la humanidad). La muerte de la víctima tiene el poder de convocar a todos los miembros de la comunidad a su alrededor; con ella la paz y la coricordia regresan y la violencia es expulsada. La función del ámbito religioso o sagrado estriba en mantener la violencia fuera de la comunidad. Así pues, si a la víctima, antes del sacrificio, se la consideraba maléfica, capaz de destruir la comunidad, tras él, ingresa en el ámbito sagrado, se diviniza, al devolver la paz comunitaria. El caracter ambiguo del sacrificio, como denunció Bataille, es bien claro: la víctima es sagrada en tanto que es sacrificada. Pero no hay dudas: es la violencia la que mata la violencia. Es la violencia la que se diviniza y sacraliza, aunque los miembros de la comunidad lo ignoren, porque para que el mecanismo victimario del mito sea eficaz es preciso que ese apasionamiento mimético contra la víctima, el todos contra uno, pase desapercibido, escape de la conciencia de los participantes, de ahí que la víctima sea culpable. Esta falta de sospecha ante el crimen, esta falta de identidad entre víctima y verdugo, es crucial en la elaboración mítica, en el comportamiento ritual, pues ésta descansa en la oscuridad y en la ignorancia, en la inconsciencia de los actos. Cuestión que pasa camuflada, tanto como las anteriores representaciones de la muerte de Cristo entre las imágenes audiovisuales en ese dulce y bello environment, en los relatos míticos, puesto que están desbordados por ella, imantados de su forma de entender el mundo. Los espacios ahistórcos de los fondos de estos cuadros, que no se adscriben a una narración concreta; las figuras,

47 BaUdRILLARD Jean. El crimen perfecto. Anagrama. Barcelona, 2000, pág. 59. 
que no señalan a un individuo específico, sino que indiferentes registran ese flujo entre intensidades, esa desterritorialización del uno en el otro fuera de nuestra lógica lineal temporal, conforman el ámbito y el sujeto del mito y del rito. Así, internados desterrados del quehacer cotidiano, exiliados como el ser del límite de Trías, el carácter simbólico de estos cuadros se origina en su potencia catártica y se fundamenta también en la importancia que sus autores otorgan al mito y al ritual, porque si Bacon amaba la tragedia griega clásica, Barceló pasa gran parte de su vida en el país Dogon, en Malí, de religión animista. En Bacon se registra toda una superposición confusa entre el mito trágico y el cristianismo: "Ese drama constituye la clave del enigma que rodea el arte de Bacon. Aunque no solía hablar de ellos en sus conversaciones, de sus cuadros se deriva claramente que se sentía identificado con los mitos, utilizándolos a modo de "armazón", como él lo calificaba, del que podía colgar cualquier tipo de sensación y sentimientos. El tema de la crucifixión dominó la primera parte de su carrera, mientras que la segunda estuvo signada por los mitos griegos, sobre todo por La Orestiada (...) En este sentido se podría afirmar que los años previos a su madurez. Bacon se identificaba con Cristo y, a medida que se fue haciendo viejo, con Orestes acosado y atormentado" ${ }^{48}$. Las furias de la culpabilidad, que sustituyen a las dolientes mujeres a los pies de la cruz, que braman su rabia cruel contra el sacrificio, pertenecen al mito, a ese ámbito sin concesiones del símbolo que las metamorfosea en monstruosos penes dentados. La lucha, la carne que se subleva contra el cuerpo férreo que la mantiene sujeta, que se desterritorializa y se lanza fuera de sí misma para encontrar la violencia real de lo que intenta representar, nada tiene que ver con la correcta figura del hombre clavado en la cruz. Y ésta, que no aparece en los cuadros de Bacon y que apenas se esboza esquemáticamente en Somalia 92 y Caballo crucificado, no se precisa porque su porosidad es carne. La cruz no se necesita cuando el dolor convierte el cuerpo en soporte del tormento. El dolor transforma la madera en carne, la pintura en materia. $Y$ es la misma búsqueda, el mismo afán por entender y ver con claridad, por llegar al nervio de la experiencia, a la imagen viva que concentre la realidad, por la que se trabaja incansablemente. Una imagen precisa que sea nervio, carne tensa, puro mensaje actual y que cuando no llega provoca un profundo desaliento. Barceló nos dice: "Y como no sucede nada parecido me embrutezco, hasta altas horas, hasta el agotamiento, ennegreciendo estos carnets con mis jeremiadas innobles, consciente de que, porque nunca tiro nada (destruyo,

48 Peppiatt Michael. Op. Cit., pág. 327. 
borro, pero guardo los cadáveres), todo ello reaparecerá como una enfermedad hereditaria. Y con esta vocación de Cristo que recuerdo haber tenido ya desde niño, me lo tragaré de nuevo, pobre santo vicioso que cae en todas las tentaciones y que no sabe escribir ni hebreo ni francés, y que, a falta de Biblias y apóstoles, pinta de día sus temores y a falta de oraciones se vacia por la noche a base de pajas" "49. Tensión extrema del trabajo que se superpone a la gravedad febril con la que se aborda el lienzo; vocación de Cristo que, paralela a la identificación baconiana con éste, vuelve a establecer esa fuga de intensidad entre lo que se quiere representar y queda plasmado, entre la vida y la pintura. Así, acerca del sentido del rito sacrificial, que en su caso se intuye tanto en la matanza del cerdo que hacian en Felanitx como en las prácticas animistas del país Dogon, Barceló comenta: "Participo en los funerales y en estas ceremonias, que las hay continuamente, que a veces duran dias y noches enteras con tambores, bailando. Es entonces cuando salen las máscaras. Sobre todo cuando es el funeral de un viejo importante. $Y$ sin duda esto influye mucho en mi trabajo, pero no como iconografía, no creo que haya modificado excesivamente mis imágenes. Es algo mucho más profundo, que está incluso relacionado con la idea del sacrificio, con la idea de los ciclos: muerte y crecimiento. Es muy animista, desde luego" "50.

Esta ilación entre pintura y vida, esta identificación compleja y profunda con Cristo de ambos (muy cercana a la leyenda del artista del siglo XIX) establece una trama en la que la catarsis irónica es fundamental. Mediante ella, de la que Girard afirma: "La palabra catarsis designa, en primer lugar, la "purificación" que provoca la sangre derramada en los sacrificios rituales" ${ }^{51}$, se vehiculiza toda una corriente intensa entre nociones y prácticas culturales distintas, al aparecer tanto en el mito (tragedia griega clásica y animismo), como en el arte y en la crucifixión cristiana. La catarsis, irónica ante un mundo desquiciado, se presenta como todo un agenciamiento cultural, toda una desterritorialización, que promueve, lejos de la identificación simplista con el héroe o la víctima y la observación placentera a la que daría pie, esa conmoción sensible ante la imagen, ese choque brusco de los sentidos antes señalados, que es la apertura de un espacio reflexivo por parte del espectador, la posibilidad de esa distancia de entendimiento y comunicación que la saturación audiovisual impide en relación con las imágenes y en la que arrastra a la representación iconográfica anterior.

\footnotetext{
49 Barceló Miquel. 'Cuadernos 15.V.95', recopilado en el catálogo de la exposición Miquel Barceló 1987-1997. Op. Cit. (págs. 10-29), pág. 168

50 Ribas José. Op. Cit., pág. 43.

51 Giraro René. Veo a Satán caer como el relámpago. Anagrama. Barcelona, 2002, pág. 59
} 
Bacon escribe sobre la purgación que provoca el arte: «Nunca he sabido por qué son consideradas horribles. Siempre me etiquetan con la palabra horror, pero jamás pienso en él. (...) ¿Podrias calificar al famoso altar de Isenheim como una obra horrorosa? Es una de las mejores pinturas de la crucifixión, con el cuerpo tachonado de espinas como clavos, pero con una habilidad tal que eleva la forma y aleja de ella el horror. Sin embargo, ¿no es al mismo tiempo un gran horror en el sentido de que es algo tan real? ¿No fue asi como la gente calificó las grandes tragedias griegas, el Agamenón? La gente surge purgada en la felicidad, en una mayor realidad de la existencia” ${ }^{52}$. La catarsis violenta, la convulsión de los sentidos, religa al hombre con la vida y la realidad. Le hace tomar conciencia, sentido, de su ubicación en el mundo. $Y$ es así como debe entenderse la afirmación de que estas crucifixiones, que registran la violencia que institucionaliza el ámbito divino, son religiosas, pues se atienen al sentido de la palabra religión, que deriva del término latino religio, -onis, que a su vez procede de religare (ligar, reunir, recoger): recogen sentido, sensibilidad. No hay mayor sensibilidad que la de devolver la realidad de lo acaecido a su ámbito de pertenencia; no hay mayor sensibilidad que la de ese Cristoraíz deshecho en fuente de vida, en alimento y raigambre, justo en su muerte. Nunca hasta ahora se había representado tan sinceramente la transferencia entre la cruz, el árbol de vida cristiano, y el ser que la dota de dicha vida al morir en ella.

Un símbolo, como algo que se atiene a diferentes secuencias espaciotemporales, está sujeto a cambios (modificaciones semánticas e intensivas, variaciones icónicas o estructurales, etc.), de ahí su gran permeabilidad cultural, pues si bien puede ser válido durante siglos, también registra sensiblemente las características de una época concreta, y si en una etapa fue relevante, en otra puede dejar de ser operativo: perder el vínculo con el lenguaje y la sensibilidad del momento. Como símbolo que experimentó un gran auge en el siglo XIII, con el afán de los movimientos religiosos propulsados por san Francisco de Asís y san Bernardo de Clairvaux, que intentaban proyectar una imagen más humana y cercana de Dios, la crucifixión no sólo terminó siendo el signo del amor de Dios y su sacrificio por la humanidad, sino también el foco icónico que registraba la compasión humana por su sufrimiento (de ahí que las imágenes académicas no se “ensañen» con él), y es a esta segunda premisa a la que más se ha abocado. Más que representar la crucifixión, las anteriores representaciones desean borrarla, anularla. $Y$ en este sentido son verdaderas

52 Pepplatt Michael. Op. Cit., pág. 322. 
mentiras. Por supuesto que se ajustan más a la imagen humana, al rostro conocido que los cuadros de Bacon y Barceló, pero precisamente por ello no dejan de ser meros formularios que recogen un suceso en el mismo sentido en que Adorno afirmaba que los documentos con los datos precisos del hecho en cuestión registran con menos exactitud la historia de la humanidad que las obras de arte, pues éstas la configuran expresivamente, la dotan de corporeidad. Las anteriores representaciones no traducen ni el sacrificio ni la situación del hombre contemporáneo, están desajustadas, desacopladas respecto de la sensibilidad actual y del símbolo que representan; se pierden en la vaguedad estática de la belleza, en el acuerdo armonioso entre el representado y los sentimientos piadosos que se desean incitar hacia él. Y en este sentido no generan experiencia. La corporeidad, el cuerpo físico de la historia, del suceso terrible que tuvo lugar, está en los cuadros de Bacon y Barceló. La obra de arte dota de corporeidad, de «fisicidad", es decir, de errores y mancha, de presencia humana, a lo que representa; sólo así puede generarse experiencia, producirse una catarsis (una forma de estar diferente) y una aisthesis (una percepción distinta) que vinculen al hombre con su mundo, que lo hagan partícipe no sólo de la realidad que lo rodea sino protagonista de su vida: ser consciente. Las anteriores representaciones olvidan las fisuras, los roces inadecuados pero necesarios, ineludibles, para la existencia. Esos devaneos nocturnos en los que el hombre se pierde entre sombras, en los que recupera la voz sosegada de su tiempo propio, de ese espacio vital que el sistema productivo poscapitalista le niega en tanto que dirige su ocio, en tanto que lo cubre por completo, hasta la asfixia, con una programada imagen falsa de sí mismo, con una imagen audiovisual con la que no es necesario pensar, pues la voz que la acompaña y constituye agota toda posibilidad de que el hombre ponga en marcha su capacidad de enjuiciamiento, de decisión.

Las obras de arte permiten, e impulsan, transformaciones. $Y$ en tanto que imágenes, son arriesgadas, se la juegan. ¿Qué arriesgan las anteriores representaciones? El arte va por delante del hombre y llega a donde a él no se le permite la entrada: las crucifixiones de Bacon y Barceló entran en el sentido oculto, terrorífico y fascinante, de la crucifixión, y comprometidas con su tiempo de vida, dejan que en ellas lata el terror de las grandes tragedias humanas que han asolado este mundo. Saben que la víctima y el verdugo son la misma persona.

Girard señala que en los textos la gran diferencia entre los demás relatos míticos y los Evangelios estriba en que en los primeros, imbuidos por el espíritu mítico, no se esclarece ni revela el mecanismo victimario, sino que se absuelve a los perseguidores y se condena a las víctimas, mientras que en los Evangelios se señala de una manera exacta la violencia colectiva: 
desde un principio se indica la inocencia de la víctima sacrificada (Cristo) y se cuestiona lo sucedido, es decir, se desbarata la homogeneidad de conciencia que caracteriza al mito (la inconsciencia de los participantes); se deja al descubierto el mecanismo victimario en cuanto hay personas (discípulos, etc.) que indican su inocencia. Si las crucifixiones de Bacon y Barceló mostrasen un cuerpo bello y ordenado, participarían de esa inconsciencia. La tacharían y limpiarian como las anteriores. Estos seis cuadros dejan entrever la violencia a la que se pretende dar término, el chivo expiatorio (el otro ajeno) al que se culpa de todo. Señalan que esta violencia está profundamente enraizada en el ser humano, que esa crueldad insospechada que sacude a la comunidad no se debe a un ser externo sino a sus miembros. La víctima y el verdugo son uno, pues la violencia está atada a ese deseo imitativo que hace al ser humano persona. La violencia, como la velocidad programada del sistema productivo con el desechable y sustituible objeto industrial, hace a los hombres intercambiables, semejantes. De ahí esas masas indiferenciadas de huesos, carne y vísceras que simulan una lucha fratricida en la cama tanto del panel central de Tres estudios para una crucifixión, como en el primer panel de Crucifixión. De ahí también que esa sombra detrás del Cristo-raíz no concuerde con su figura, sino con la de un animal. Es la sombra del otro, de la mímesis violenta: es el cuerpo humano sufriente que todo sacrificio ignora. La sombra se ha hecho carne, cuerpo. Ha olvidado su forma etérea para hablar del hombre actual, para indicar su violencia ignorada, su desfiguración dentro de sí mismo. La violencia dota de cuerpo a la sombra, que toma la figura de un caballo o asno, animales que han sido víctimas sacrificiales en varias culturas y que representan el símbolo del movimiento cíclico de la vida. Y así, extrapolando la figura del otro, imprescindible para el sostenimiento comunitario, al enfrentamiento entre la imagen simbólica y la audiovisual, debemos preguntarnos si las crucifixiones de Bacon y Barceló no actúan también como esos pharmakós griegos o chivos expiatorios; si acudiendo a una imagen-otra, a un ser "cristológico" (en tanto que sacrificiable) pero que no es Cristo, no están recuperando la fuerza catártica de la imagen simbólica. Ese poder revulsivo, ese plus de sentido que la caracteriza. Las crucifixiones de Bacon y Barceló conocen el papel social, institucionalizador, de ese otro y como tal lo pintan. $Y$ se valen de esa imagen incongruente, de esa "otredad" exasperada y límite, para denunciarlo. Ellas mismas son una imagen-otra en tanto que nada se parecen a las anteriores. Intuyen que en el fondo subyace la verdad del devenir humano, pues la figura del otro indica los márgenes, la frontera; ese ámbito donde los conceptos se aventuran y enriquecen entre sí, esa sospecha terrible que identifica al verdugo con la víctima. 


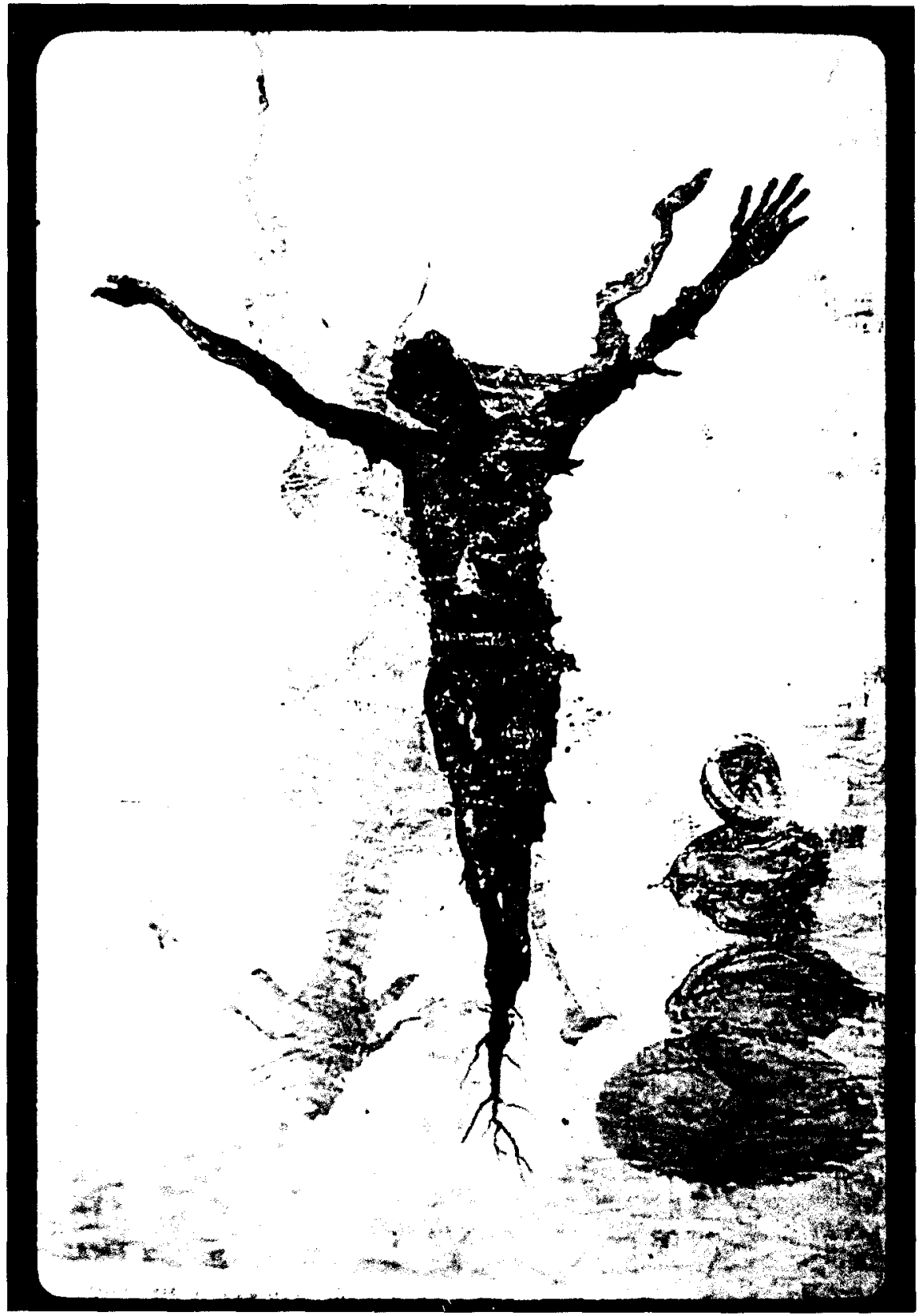

Fig. 9. Cristo Raíz. Autor: Miquel Barceló (1998), técnica mixta en papel montado sobre lienzo. $408 \times 280 \mathrm{~cm}$. Zúrich, Galería B. Bischofberger. 
Es curioso comprobar cómo esa veta de ocultación insospechada e inconsciente que aparece en los mitos se relaciona con la estructutra programada del sistema actual: el hombre no debe conocer a su prójimo, al otro. No le interesa al sistema, dado que en ese acercamiento entre ambos puede reconocerse que sólo nos diferencia y separa la absurda rivalidad mimética, que nada más allá de los instintivos mecanismos primarios, que el sistema manipula mediante miles de fórmulas (psicológicas, sociales, culturales, etc.), nos hace antagonistas. No es extraño que el simulacro filtre la vida de los otros por medio de la pantalla televisiva, que nos haga llegar sólo aquello que le interesa que conozcamos y que no suponga ningún peligro para su estabilidad, pues siempre se necesita de un chivo expiatorio para calmar las disensiones internas, y nada más fácil para ello que remover las ascuas de la violencia contra el diferente, nada más sencillo que incitar la rivalidad contra el desconocido. Las crucifixiones de Bacon y Barceló son muy peligrosas en este sentido, pues tiran la máscara al suelo, vulneran la hipocresía del status quo. Reconocen el juego del simulacro, indican que el otro, ese ser del extrarradio, de esa zona del medio indefinida sin principio ni fin, sin pertenencia alguna, es el chivo expiatorio del que la paz del sistema se nutre. Rizomáticas por completo, manejándose en ese "estar en el medio" de Deleuze y Guattari, esa diferencia constante entre intensidades que genera el fluir entre el no ser y el ser y que se identifica con el lenguaje simbólico (ese ir del mito, tragedia griega clásica y animismo al relato bíblico y viceversa) lo denuncian. Y esta postura acusatoria las diferencia del asentir callado de las anteriores y de la transparencia de la imagen audiovisual. Estas crucifixiones abruptas y descarnadas, atormentadas como la herida que son, saben que Dios es comida y se lo comen. Saben que representan la muerte sacrificial y la llevan a cabo. No mienten, no son hipócritas. Ricas, repletas de experiencia, de intensidad y riesgo, miran cara a cara a ese ser crucificado, y encuentran al hombre, al animal y al tubérculo: un banquete completo. Una eucaristía sacrílega para los tiempos que corren. El arte denuncia, el arte señala. Levanta la mano y mete el dedo en la llaga. EI arte es mirada desesperada ante sí mismo. Las crucifixiones de Bacon y Barceló señalan que detrás de la representación iconográfica anterior de la muerte de Cristo se esconde esa transubstanciación inversa y pagana, contraria a la cristiana, que el hombre realiza a diario desde tiempos inmemoriales. Tildan de sacrílego el mecanismo victimario y por ello se vuelven sacrílegas: "La irrespetuosidad hacia el tema (...) lo hace de nuevo fructífero, le devuelve la potencia expresiva y hasta, paradójicamente, su significado primigenio porque nos sitúan de nuevo ante el evento trágico. Como ha señalado Jürgen Moltmann, teólogo cristiano, el carácter trágico, 
violento y escandaloso de la crucifixión se ha perdido en el cristianismo, mientras que su evidencia se hace patente para el ateo" ${ }^{53}$. En esta eucaristía sacrilega, en la que la materia y la carne se confunden, ya no es el Verbo el que se hace carne, sino la carne la que se hace verbo. En estos cuadros, por encima de los que Barceló anda como Pollock y por los que ruedan los alimentos que pinta y que Bacon termina con su propia mano (esa mano-pincel que en Barceló ya es mano-animal con las termitas), se produce todo un trasvase entre artista y cuadro que borra la distancia entre objeto y sujeto, al igual que sucede desde el body art, con el que el cuerpo del artista se convertía en el soporte mismo del mensaje (Gina Pane, Orlan, etc.). Un trasvase que se equipara al que denuncian estos cuadros: identidad de víctima y verdugo; yo es otro; la carne y la materia son pintura. La inversión de la fórmula de la eucaristía cristiana: ya no es Dios quien se transfigura en pan y vino, ya no es su cuerpo y sangre los que están en estos alimentos, sino que por el contrario, son el pan y el vino los que están en el cuerpo y la sangre de Dios. Dios es comida: a Dios se le fermenta y amasa.

Si en el relato bíblico de la creación (como en casi todos los relatos míticos) se instaura el orden en el caos original y se apartan la oscuridad y las tinieblas mediante la palabra (el Verbo hecho carne), ahora, tras la desvirtuación semántica y sintáctica de ésta por el simulacro, tras su excesiva exposición, se atisba como única salida proceder inversamente: el cuerpo es la palabra del hombre, el reducto último de significado (sabemos del color, de la alegría, la pena y la nostalgia por él); la palabra es corpórea, porque la densidad y la veracidad que entraña la carne no pueden ser suplidas por las avanzadas técnicas contemporáneas. Se trata de la visión gastronómica de la eucaristía, de su concepción como ágape festivo y transgresor, del significado antropológico de la muerte de Cristo, su contemplación como regeneradora del status quo comunitario.

Las anteriores representaciones son las que cometen la falta, pues no hacen justicia a la crucifixión. Cómplices del simulacro por su falta de adscripción sociohistórica, no traducen antropológicamente el sacrificio de Cristo, sino que remiten al mito cristiano, pues actúan, contrariamente a como lo hacen los Evangelios según Girard, del mismo modo que el relato mítico: guardando el secreto, ocultando la verdad de la violencia intestina (individual) de los miembros de la comunidad, negando la inocencia de la víctima y haciéndola culpable, incapaces de identificar sus propios

53 Vozmediano Elena. Op. Cit., pág. 22. 


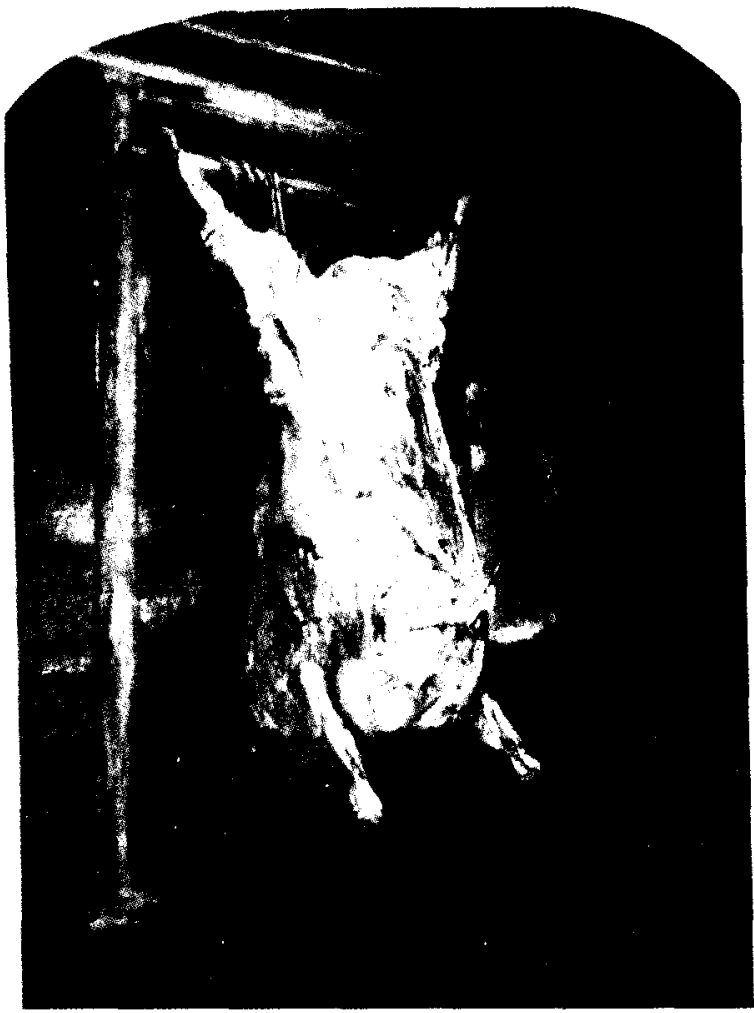

Fig. 1. El buey desollado. Autor: Rembrandt (1655). Óleo sobre madera, $94 \times 67 \mathrm{~cm}$. Paris, Museo Nacional del Louvre:

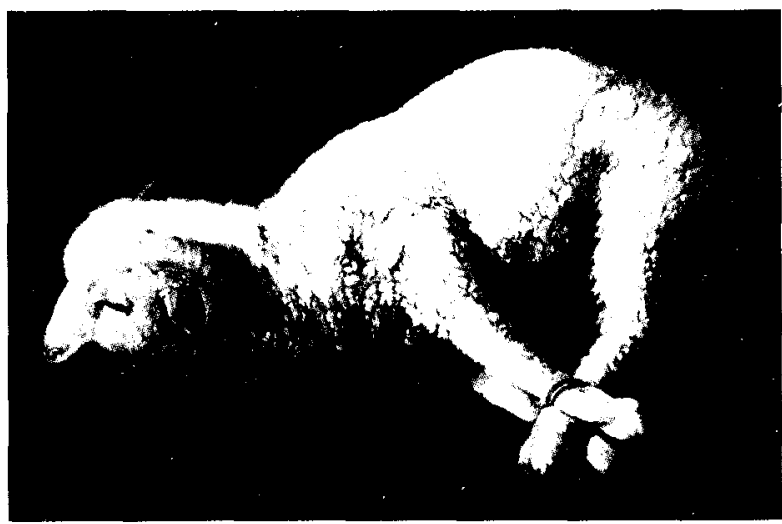

Fig. 3. Agnus Dei. Autor: Zurbarán. (1635/40). Óleo sobre lienzo, $38 \times 62 \mathrm{~cm}$. Madrid, Museo del Prado. 
sentimientos. Lo que el relato bíblico proclama es el rechazo de la violencia, cuestión que estos cuadros desvelan mediante el mecanismo simbóli$\mathrm{co}$, es decir, aunando la potencia conjuntiva y la disyuntiva, debatiéndose entre el no ser y el ser, haciendo que las diferentes conexiones entre el mito y el relato bíblico interactúen en esos márgenes entre mentalidades, en esos extrarradios intelectuales de los que se satisface la posmodernidad. Aunque no hay diferencia estructural entre el sacrificio de Cristo y el de cualquier héroe mítico (en ambos casos actúan ciclos miméticos y ambos contienen los tres momentos de éstos: la crisis, la violencia colectiva y la epifanía divina), sí que se da en el primero una diferencia en cuanto a ese distanciamiento que posibilita su representación y que permite a los participantes desentenderse de la unanimidad y del acto en sí, que permite la critica y el rechazo de la violencia. Distanciamiento y representación que se vuelven a encontrar en cualquier experiencia estética auténtica (catarsis), que nada tiene que ver con la plasmación plástica de un hecho, y sí con dejarse sacudir por él. La obra de arte, siempre cercana a su origen, que en su propia puesta en pie se expone a sí misma tanto como a lo que representa, es capaz de intuir el entramado de conexiones y reciprocidades entre diferentes sistemas culturales o modos de explicarse la vida. Descubre que el sistema dual de pensamiento sólo roza la superficie del acontecer humano, que éste se deslinda y desenvuelve fuera, en esas zonas de paso o de fluctuación en las que las diferencias dojan de serlo e interaccionan ampliando y enriqueciéndose entre sí.

Si el rostro trae consigo el primer significado, en ese cara a cara que funda el lenguaje para Lévinas, ¿cómo se modifica la capacidad de comunicación del hombre cuando no se ve al otro, cuando no se conoce su verdadera faz? ¿Cuándo, como en esta época, el propio yo se deslinda de sí mismo? La imagen preestablecida del rostro de Cristo condensa todas las maneras que hay que contemplar para ser uno con el mundo, uno con la sociedad. Basta parecerse a ese perfecto modelo para ser aceptado, y en este sentido las anteriores representaciones han venido funcionando sólo como códigos icónicos: su rostro-rastro divino abstrae y concentra lo supuestamente genuino del ser humano (el ideal de perfección, de parentesco con Dios, lo humano menos humano del hombre), mientras que olvida la parte más esencial e imposible de sintetizar (su corporeidad o materialidad, su falta, su mancha). El hombre sin cuerpo, sin los ámbitos oscuros e ingobernables de éste, es el rostro de Occidente. Y esto ha sido así porque para la ortodoxia católica el cuerpo era un lastre que mantenía al alma encarcelada y no era digno de ser reproducido. Se debía mirar a lo alto para entrar en contacto con el altísimo, y en esas alturas ideológicas, el cuerpo, tan terrenal y mortal, era un lastre. Se podía prescindir de él, si 
después de todo y tal como sostiene Azara, era una mera mortaja terrenal que tenía que desaparecer sin remisión, con lo que el rostro era el canal ideal para transferir la plegaria, la norma elevada y suprema hacia Dios, pues apenas rozaba la corporeidad y sin embargo conservaba aún el aspecto humano. De ahí que el rostro por excelencia haya sido el de Cristo, ya que es el hijo y la imagen (ambos términos, typos en griego) de la que Dios se sírvió para manifestarse ante el hombre. A lo largo de la historia, la pintura ha utilizado todos los recursos de este Cristo-rostro y ha establecido en torno a él tanto las unidades como las desviaciones de la persona; desde la edad media, Cristo ha elaborado la rostrificación, ha compuesto los rostros comunes valiéndose de todas las variaciones (Cristo manierista, Cristo negro, Cristo indio suramericano, etc.). Por el contrario el aspecto humano se ha reducido al límite en las crucifixiones de Bacon y Barceló. El rostro en ellas es la ausencia de faz; saben que no hay cara visible que no mienta ni para Dios ni para el hombre.

Jean Clair afirma que el arte es hablar cara a cara, atreverse a llamar a las cosas por su nombre en una justeza radical de la palabra y la imagen. ¿Cómo poder hablar con este mundo a través de la imagen tradicional de Cristo? Si para que Dios fuese visible fue necesario que se hiciera aprehensible por medio de la representación (encarnación) en el cuerpo humano, y de ahí a su plasmación plástica; perdida la ligazón de la antigua mirada, del lenguaje anterior, ¿no será necesario para hablar cara a cara, para poder dar testimonio de la equivalencia entre razón, sentido y lenguaje (es decir, cierto deseo y capacidad comunicativos entre los hombres), el cambio de registro de esa representación plástica y el reconocimiento de su significado? Si el hombre está hecho a imagen y semejanza de Dios, la separación de éste o su ocultación acarrea la pérdida de la imagen humana. El rostro no responde a la verdad. Steiner subraya: "Sólo en lo estético existe la absoluta libertad de "no haber llegado a ser". Por paradójico que resulte, es esta posibilidad de ausencia la que otorga fuerza autónoma a la presencia de la obra" ${ }^{54}$. Sólo en la obra de arte se muestra ese rostro oculto sin que su ausencia sea una falta; sólo el arte tiene la capacidad de dotar de densidad y presencia a la vacuidad. Sólo él puede recoger el fuego de la memoria de lo que no ha sido ni será pero que sin embargo es. Extraña y conmovedora paradoja. El arte "hace ver en presente lo que no se ve en presente, pero que está en él" ${ }^{55}$. Y para ello hay que pasar la pared, devenir animal, tubérculo, carne, pintura, ma-

\footnotetext{
StEINER George. Presencias reales. Destino. Madrid, 2001, pág. 199.
}

WAJCMAN Gérard. Op. Cit. 24. 
teria. Se trata de traspasar la pared del significante, de lo que siempre se nos ha dictado, del nombre y rostro conocidos. Se trata de encarar la ausencia y reconocerse en ella. De enriquecerla y asumirla. No desconocemos el rostro que no se deja ver, nuestra ignorancia, nuestra terrible y maravillosa oscuridad, lo conoce. Hay que asumir el riesgo, tomar el testigo. Hay que moverse, no dejar de hacerlo dentro de uno mismo, aproximarse al otro. Se trata de negarse a reconocer un estado dado, inalterable e inerte, de que nuestro ojo sea ojo y nos pertenezca. 
